\title{
2- Anlatıcı kavramının ortaokul Türkçe ders kitaplarına yansımaları
}

\section{Burcu ÖZTÜRK' \\ Seher ÇİÇEK²}

APA: Öztürk, B.; Çiçek, S. (2021). Anlatıcı kavramının ortaokul Türkçe ders kitaplarına yansımaları. RumeliDE Dil ve Edebiyat Araştırmaları Dergisi, (25), 18-37. DOI: 10.2900o/rumelide.1032361.

Öz

$\mathrm{Bu}$ araştırmada ortaokul Türkçe ders kitaplarında anlatıcı kavramının nasıl bir görünüm sergilediğinin belirlenmesi amaçlanmıştır. $\mathrm{Bu}$ amaçla araştırma tarama çalışması şeklinde düzenlenmiştir. Doküman inceleme yöntemiyle toplanan araştırmanın inceleme nesnelerini; MEB ve özel yayınevlerinin ortaokul Türkçe ders kitaplarında yer alan seksen yedi öyküleyici metin oluşturmuştur. Araştırmanın sorun ve alt sorunları temelinde elde edilen verileri çözümlemek için nitel veri analizi yöntemlerinden biri olan betimsel analiz kullanılmıştır. Yapılan betimsel analizler sonucunda MEB ve özel yayınevlerinin incelenen öyküleyici metinlerinde; en fazla nesnel odaklayımın, ikinci sırada ise öznel odaklayımın bulunduğu; bu metinlerde sırasıyla elöyküsel, benöyküsel ve senöyküsel anlatıcı türlerinin kullanıldığı gözlemlenmiştir. Ayrıca MEB ve özel yayınevlerinin ortaokul Türkçe ders kitaplarında yer alan öğretim etkinliklerinde anlatıcı kavramına yer vermede tutarsızlık olduğu belirlenmiştir. Bu öğretim etkinliklerinin birbirine benzer şekilde metin çözümleme üzerinde yoğunlaştığı, buna karşın metin üretmeyle ilgili etkinlik kurgulanmadığ görülmüştür. Bu sonuçlara ek olarak incelenen ders kitaplarının büyük çoğunluğunun metin içi sorularında yazar ve anlatıcı karmaşasının bulunduğu tespit edilmiştir. Buna göre ortaokul Türkçe ders kitaplarında metin çözümleme ve üretmenin önemli bir parçası olan anlatıcı türlerinin dağılımı sınıf seviyesine göre düzenlenebilir ve bu kavramla ilgili öğretim etkinliklerinde tutarlık ve üretkenlik artırılabilir. Ayrıca ders kitaplarında bu kavramla ilgili yanılgıların önüne geçmek için yazar ve anlatıcı ayrımı sağlanabilir.

Anahtar kelimeler: Anlatıcı, metin, odaklayım, öyküleyici ortaokul Türkçe ders kitabı, yazar

\section{Reflections of the concept of narrator on secondary school Turkish textbooks}

\author{
Abstract \\ In this research, it is aimed to determine how the concept of narrator displays in secondary school \\ Turkish textbooks. The examination objects of the research collected by the document analysis \\ method; eighty-seven narrative texts in secondary school Turkish textbooks of MEB and private \\ publishing houses were created. Descriptive analysis was used to analyze the data obtained on the \\ basis of the problems and sub-problems of the research. As a result, in the analyzed narrative texts of \\ both publishing houses; the highest objective focalazition, followed by subjective focalazition; in \\ these texts, it has been observed that the narrator genres are the first person narrator, the second \\ person narrator and the third person narrator, respectively. In addition, it has been determined that \\ there is an inconsistency in including the concept of narrator in the teaching activities the secondary \\ Dr. Öğr. Üyesi, Kastamonu Üniversitesi, Eğitim Fakültesi, Türkçe Eğitimi Bölümü (Kastamonu, Türkiye), \\ bozturk@kastamonu.edu.tr, ORCID ID: 0000-0002-4087-3370 [Araştırma makalesi, Makale kayit tarihi: 11.09.2021- \\ kabul tarihi: 20.10.2021; DOI: 10.29000/rumelide.1032361] \\ Dr., Türkçe Öğretmeni, Düzce MEM (Düzce, Türkiye), sehertabak123@gmail.com, ORCID ID: oooo-ooo2-1501-2675 \\ Adres | Address \\ RumeliDE Dil ve Edebiyat Araştırmaları Dergisi \\ Osmanağa Mahallesi, Mürver Çiçeği Sokak, No:14/8 \\ Kadıköy - ISTANBUL / TÜRKIYE 34714 \\ e-posta: editor@rumelide.com \\ tel: $+905057958124,+90216773$ o 616 \\ RumeliDE Journal of Language and Literature Studies \\ Osmanağa Mahallesi, Mürver Çiçeği Sokak, No:14/8 \\ Kadıköy - ISTANBUL / TURKEY 34714 \\ e-mail: editor@rumelide.com, \\ phone: +90 $5057958124,+902167730616$
}


school Turkish textbooks. It has been observed that these activities are focused on text analysis similar to each other, however, there is no activity related to producing text. In addition to these results, it has been determined that the majority of the examined textbooks have author and narrator confusion in the in-text questions. Accordingly, the distribution of narrator types, which are an important part of text analysis and production in the textbooks, can be arranged according to grade level, and consistency and productivity can be increased in teaching activities related to this concept. In addition, in order to avoid misconceptions about this concept in textbooks, a distinction can be made between author and narrator.

Keywords: Narrator, author, focalazition, narrative text, secondary school Turkish textbook

\section{Giriş}

Metinlerin bilgi verme ve haz verme gibi iki temel amacı vardır. Bu temel amaçlara göre metinler farklı şekillerde sınıflandırılmıştır. Türkçe Öğretim Programı'nda (2018) metinler bilgilendirici, hikâye ve şiir olmak üzere üç grupta değerlendirilmekte ve ders kitaplarına metin seçimi bu gruplama temelinde yapılmaktadır. Ayrıca bunların dengeli bir şekilde dağıtılması ilkesi bulunmaktadır (MEB, 2018).

Hikâye, roman, masal, fabl gibi hikâye edici metinler kurmaca metinlerdir. Temel dayanağı kurgu olan bu türler, estetik haz verme amacı taşır ve bunlar imgelemsel bir gerçekliği yansıtır (Sever, 2013; Şen, 2020; Dilidüzgün, 2004). Kurmaca metinlerin temel bileşenleri olan olay örgüsü, mekân, zaman, şahısvarlık kadrosu ve anlatıcı ortaokulun her sınıf düzeyindeki okuma kazanımları arasındadır (MEB, 2018).

Anlatı üretimi veya anlatmak eylemi olarak tanımlanan öykülemede kim anlatıyor ve nasıl anlatıyor soruları cevaplandırılmaya muhtaçtır (Sözen, 2008). Bütün kurmaca metinler, temelde bir olay örgüsü yani hikâye ile bunu aktaran bir anlatıcıya (narrator) dayanır. Bu iki unsur anlatıların en temel değişkenleridir (Sözen, 2008; Tekin, 2009). Hatta bu hiyerarşide anlatıcı en üsttedir. Çünkü anlatıcı kurmaca metinlerin temel unsuru, aynı zamanda en etkili figürüdür. Anlatıcı olmadan hikâyeyi anlatmak, olayları okura aktarmak, kahramanları tanıtmak mümkün değildir (Tekin, 2009). "bilmek" anlamına gelen Yunanca gnarus kelimesi Yunancada anlatı ve anlatıcı sözcüklerini karşılar. O halde anlatıcı bilen kişidir ve bu bilginin iletildiği süreç anlatıdır (Beard, 2003, s. 33). Anlatıcının başka bir işlevi de konu ile izleyici arasındaki bağlantıyı kurarken, eserin biçemini geliştiren unsur olmasıdır (Sözen, 2008).

$\mathrm{Bu}$ araştırmanın temel sorunu olan anlatıcı yazarın öyküyü, öyküleme çizgisi üzerinde okura aktarması için metne yerleştirilen sestir (Beard, 2001; Bennett ve Royle, 2016; Günay, 2003). Anlatıdaki olayları aktaran, yazarın yarattı̆̆ı, sadece metnin içinde yaşayan varlık anlatıcıdır (Demir, 2008). Bütün kurmaca metinlerin ortak bir özelliği de yazarları dışında anlatıcılarının olmasıdır. Romanlarda bazen birden çok anlatıcı kullanılsa da öykülerde genellikle anlatıcı tektir (Gülsoy, 2014). Anlatıcılar, öyküyü anlatması için yazar tarafından seçilmiş, yaratılmış, kurmaca kişilerdir ve tıpkı öykü kahramanları gibi soyuttur, yaşanılan gerçek dünyada karşılıkları yoktur (Sözen, 2008). Bu bağlamda yazarla anlatıcı aynı varlık değildir. Yazar, metnin üreticisiyken; anlatıcı, anlatının temel ögelerinden biridir; bir okuyucu metni okuduğunda gerçekleşen kavramdır (Kıran, 2003, s. 95). Başka bir deyişle anlatıcı, yazardan yetki alıp kurgudaki olayları anlatan; okuma sırasında ortaya çıkıp okuma bittiğinde kaybolan biridir (Demir, 2008). Bir anlatı dilsel bildirişim olduğu için anlatı okunduğunda anlatıcı ve dinleyici birliktedir (Barthes, 2005, s. 125). Bu nedenle bu ayrıma göre yazar ile okur gerçek hayata ait kişilerdir; anlatıcı ve

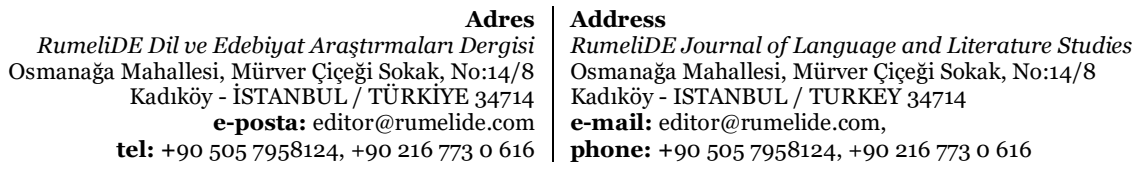


dinleyici ise anlatıya ait varlıklardır (Sinan ve Demir, 2021). Yazın okuryazarlığı açısından bu ayrıma yönelik okurun farkındalığı eleştirel okumanın ilk aşamasıdır (Şen, 2020).

Bir anlatının en önemli bileşenlerinden biri olan anlatıcı okuyucunun karşısına üç türde çlkmaktadır. Bunlar: benöyküsel, senöyküsel ve elöyküsel anlatıcıdır (Beard, 2003; Özdemir, 2007; Tekin, 2009). Öykünün bütün biçemine hâkim olan bu sınıflandırmada benöyküsel anlatıcı ben veya biz adıllarıyla; elöyküsel anlatıcı o veya onlar adıllarıyla; senöyküsel anlatıcı ise sen veya siz adılları kullanılarak oluşturulur. Bu anlatıcı türlerinin okuyucular için ortaya çlkarabileceği birtakım olumlu ve olumsuz taraflar olabilir. Söz gelimi; benöyküsel anlatıcının kullanımında okuyucu yazarla anlatıcıy birbirine karıştırabilir. Buna karşın, okuyucu için bu türün kullanımı metnin inandırıcılığını da artırır (Demir, 2008). Bu anlatıcı türlerinin birbirine üstün tarafları göz önüne alındığında anlatıcı seçiminin doğurabileceği olumlu ve olumsuz durumlara dikkat edilmelidir. Metin çözümlemede bu durumlar öğrencilerle birlikte tartışılmalıdır. Bu sayede öğrencilerde anlatıcı türlerinin sunacağı fırsatlara ilişkin farkındalık oluşturulabilir (Şen, 2020).

$\mathrm{Bu}$ araştırmada ortaokul Türkçe ders kitaplarında incelenecek bir diğer unsur da odaklayım (focalazition) kavramıdır çünkü anlatıcı ve odaklayım unsurları birbirleriyle bağlantılıdır. Ancak anlatıcı-yazar ayrımı gibi anlatıcı ve odaklayım kavramları da birbirinden farklıdır. Bir anlatıda "Kim konuşuyor?” sorusunun cevabı anlatıcı, "Kim görüyor?” sorusunun cevabı ise odaklayımdır (Kıran ve Kıran, 2003). Başka bir deyişle bir anlatıda kimin konuştuğu okuru anlatıcıya, kimin gördüğüyse odaklayıma götürür. (Kale, 2017, s. 46). Kahramanları, varlıkları, nesneleri okura tanıtmak ve okuru öykülemenin içine çekmek amacı olan odaklayım (Demir, 2008), yazarın varlıkları ve nesneleri betimlemek için seçtiği bakış açısıdır (Kıran ve Kıran, 2003). Bu iki kavramın arasında birbirini tamamlayan ve sınırlayan bir ilişki vardır. Yazarın bakış açısı olan odaklayım dört türdür. Bunlar: öznel, nesnel, çoklu ve ikili odaklayımdır. Yazar amacına uygun olarak bunları tek tek veya birlikte de kullanabilir (Şen, 2020).

Sıfır odaklayım, tanrısal bakış açısı da denilen öznel odaklayımda; ayrıcalıklı bir konumda olan anlatıcı her şeyi ve her yeri bilip görür ve bunları anlatabilir. İşte bu açıdan tanrısal bir özelliğe sahiptir. Bu özelliğinden dolayı anlatıcı, kahramanların içinden geçenleri bilip olaylar veya kahramanlar hakkında yorum yapabilir (Günay, 2003; Şen, 2020). Nesnel odaklayım türünde dışarıdan bir gözlemci olarak davranan anlatıcı olayların dışında konumlanır (Şen, 2020) fakat olayların tanığıdır. Dolayısıyla gördüğü veya duyduğu olayları aktarırken olaylara yaklaşıp daha çok ayrıntılı bilgi verebilir. Olaylardan uzaklaştığında ise yüzeysel bilgi verir. Bu bilgi verme sürecinde daima yorum yapmaktan kaçınır (Demir, 2008; Kıran ve Kıran, 2003). Çoklu odaklayımda ise olayları aktaran farklı anlatıcılar bulunmaktadır. $\mathrm{Bu}$ yüzden algılanması zor olan çoklu odaklayım türünün soyut dönemde olmayan çocuklar için yazılan eserlerde kullanılmaması önerilmektedir (Şen, 2020). Son olarak görsel ve dilsel olmak üzere iki boyutu olan ikili odaklayım; görsel boyuta dayanan elöyküsel anlatıcı ile dilsel boyuta dayanan benöyküsel anlatıcının birlikte kullanılmasıyla oluşan bakış açısıdır (Şen, 2020). Özellikle resimli çocuk kitaplarında bu odaklayım türünden faydalanılır.

Alanyazında kuramsal olarak anlatıcı kavramını ele alan, bu kavramın türleri ile ilgili tespitlerde bulunan çalışmalar bulunmaktadır. Ortaokul Türkçe öğretim programı okuma kazanımları arasında yer alan bu kavramın ders kitaplarındaki metinlerdeki durumuyla ilgili araştırmalar ise oldukça azdır (Canl, 2014; Ercantürk, 2015; Demir, 2008; Sinan ve Demir, 2011; Şen, 2020). Bunlardan Demir (2008) ve Ercantürk (2015) dilbilimsel yöntemlerle Türkçe ders kitaplarında bulunan öyküleyici metinleri incelemiş, metinlerin öğrenci seviyesi uygunluğu hakkında değerlendirmeler yapmıştır. Sinan

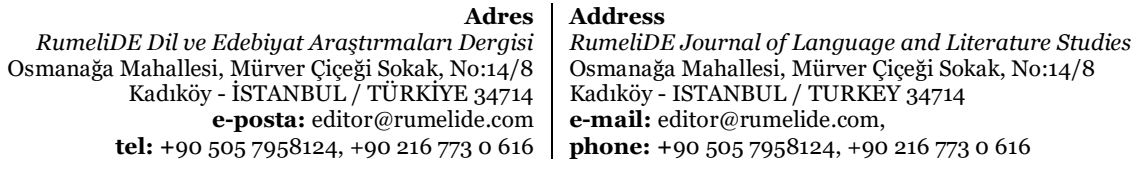


ve Demir (2011) ise Türkçe ortaokul ders kitaplarında bulunan metinlerin öğrenci anlama düzeyine, program kazanımlarına, temalarına uygunluğunu incelemiştir. Şen (2020) ise ortaokul Türkçe ders kitaplarında bulunan otuz metnin anlatıcı tür ve odaklayım dağılımını betimlemiştir. Bu araştırmada ise alanyazın çalışmalarından farklı olarak daha kapsamlı bir şekilde MEB ve özel yayınevleri ortaokul Türkçe ders kitaplarında bulunan bütün öyküleyici metinler araştırmaya dâhil edilmiş, bunların anlatıcı tür ve odaklayım dağılımları belirlenmiştir. Ayrıca anlatıcı kavramına ortaokul Türkçe ders kitaplarında yer verilme sıklık ve şekli ele alınmıştır. Bu gerekçelerden hareketle bu araştırmada ortaokul Türkçe ders kitaplarında anlatıcı kavramının nasıl bir görünüm sergilediğinin ve bu kavramın ortaokul ders kitaplarına nasıl yansıdığının belirlenmesi amaçlanmıştır. Bu amaçla araştırmanın sorun ve alt sorunları şu şekilde oluşturulmuştur:

Ortaokul Türkçe ders kitaplarında anlatıcı kavramı nasıl bir görünüm sergilemektedir?

Ortaokul Türkçe ders kitaplarında;

1. yer alan öyküleyici metinlerin (öykü, roman, efsane, destan, fabl) anlatıcı ve odaklayım dağılımı nasıl bir görünüm sergilemektedir?

2. anlatıcı öğretim etkinliklerinin sınıf seviyelerine göre yayınevlerinde dağılımı nasıl bir görünüm sergilemektedir?

3. anlatıcıyla ilgili öğretim etkinlikleri nasıl kurgulanmıştır ve bu etkinliklerde hangi terimler kullanılmıştır?

4. yazar ve anlatıcı karmaşası var mıdır?

\section{Yöntem}

Ortaokul Türkçe ders kitaplarında anlatıcı kavramının nasıl bir görünüm sergilediğini ortaya koymayı amaçlayan bu araştırma tarama çalışması şeklinde yürütülmüştür. Tarama çalışmalarında, araştırma konusu mevcut durumuyla kendi koşulları içinde betimlenir (Karasar, 2012). Evrenden seçilen örneklem üzerinde araştırma amaçlarına göre belirlenen soruların cevapları için tarama yapılır (Büyüköztürk, Kılıç Çakmak, Akgün, Karadeniz ve Demirel, 2015; Fraenkel ve Wallen, 2006).

\section{Araştırmanın inceleme nesneleri}

Araştırmanın inceleme nesnelerini; her sınıf düzeyinden MEB yayınevinden bir tane, özel yayınevlerinden bir tane olmak üzere toplam sekiz ortaokul Türkçe ders kitabında yer alan seksen yedi öyküleyici metin (öykü, roman, efsane, destan, fabl) oluşturmuştur. Şiir, tiyatro, serbest okuma metinleri araştırmanın kapsamı dışındadır. Örneklemdeki 20 metin 5. sınıf, 22 metin 6. sınıf, 28 metin 7. sinıf, 17 metin ise 8. sinıf ders kitabında yer almaktadır.

Tablo 1. Araştırmanun inceleme nesneleri

\begin{tabular}{|c|c|c|c|c|c|c|c|}
\hline & & \multicolumn{5}{|c|}{ Metinlerin sınıf düzeyi } & \multirow[b]{2}{*}{ Genel toplam } \\
\hline & & 5 & 6 & 7 & 8 & Toplam & \\
\hline \multirow{2}{*}{ Yayınevi } & MEB ortaokul Türkçe ders kitapları & 8 & 11 & 16 & 12 & 47 & \multirow{2}{*}{87} \\
\hline & Özel yayınevleri Türkçe ders kitapları & 12 & 11 & 12 & 5 & 40 & \\
\hline & $\begin{array}{r}\text { Adres } \\
\text { RumeliDE Dil ve Edebiyat Araștirmalar Dergisi } \\
\text { Osmanağa Mahallesi, Mürver Çiçeği Sokak, No:14/8 } \\
\text { Kadıköy - İTANBUL / TÜRKIYE } 34714 \\
\text { e-posta: editor@rumelide.com } \\
\text { tel: }+90 \text { 505 7958124, +90 } 216773 \text { o } 616\end{array}$ & \multicolumn{6}{|c|}{$\begin{array}{l}\text { Address } \\
\text { RumeliDE Journal of Language and Literature Studies } \\
\text { Osmanağa Mahallesi, Mürver Ciçeği Sokak, No:14/8 } \\
\text { Kadıköy - ISTANBUL / TURKEY } 34714 \\
\text { e-mail: editor@rumelide.com, } \\
\text { phone: +90 505 7958124, +90 } 216773 \text { o } 616\end{array}$} \\
\hline
\end{tabular}




\section{Verilerin toplanması}

$\mathrm{Bu}$ araştırmanın verileri, ortaokul Türkçe ders kitaplarından doküman inceleme yöntemiyle toplanmıştır. Bu yöntemin temel koşulu, araştırma amacına uygun dokümanların elde edilmesinden sonra (Karasar, 2012) araştırılacak konuyla ilgili yazılı, basılı veya sözlü dokümanların içeriğinin analizinin yapılmasıdır (Yıldırım ve Şimşek, 2013). Buna göre bu araştırmanın dokümanlarını; MEB yayınevinin 5, 6, 7 ve 8. sınıf düzeyi dört ortaokul Türkçe ders kitabında ve özel yayınevlerinin 5, 6, 7 ve 8. sınıf düzeyi dört ortaokul Türkçe ders kitabında yer alan seksen yedi öyküleyici metin oluşturmuştur. Araştırmanın inceleme nesnelerinin alındığı ortaokul ders kitapları aşağıda verilmiştir:

\section{MEB yayınevi}

\section{Sinıf Ortaokul Türkçe Ders Kitabı-MEB}

6. Sınıf Ortaokul ve İmam Hatip Ortaokulu Türkçe Ders Kitabı-MEB

7. Sınıf Ortaokul ve İmam Hatip Ortaokulu Türkçe Ders Kitabı-MEB

8. Sınıf Ortaokul ve İmam Hatip Ortaokulu Türkçe Ders Kitabı-MEB

\section{Özel yayınevleri}

5. Sınıf Ortaokul ve İmam Hatip Ortaokulu Türkçe Ders Kitabı-Anıttepe Yayınları

6. Sınıf Ortaokul ve İmam Hatip Ortaokulu Türkçe Ders Kitabı-Eksen Yayıncılık

7. sinıf Ortaokul ve İmam Hatip Ortaokulu Türkçe Ders Kitabı-Özgün Yayıncılık

8. sinıf Ortaokul ve İmam Hatip Ortaokulu Türkçe Ders Kitabı-Dörtel Yayıncılık

\section{Verilerin analizi}

Araştırmada incelenen ders kitaplarından elde edilen dokümanları çözümlemek için nitel veri analizi yöntemlerinden biri olan betimsel analiz kullanılmıştır. Bu analiz yönteminde araştırma sırasında belirlenen temalara uygun olarak elde edilen veriler özetlenerek yorumlanır (Yıldırım ve Şimşek, 2013). Bu bağlamda sekiz ortaokul Türkçe ders kitabında yer alan öyküleyici metinlerin anlatıcı türleri ve odaklayım biçimlerinin dağılımı, ders kitaplarında yer alan anlatıcı öğretim etkinliklerinin sınıf seviyelerine göre dağılımı, anlatıcıyla ilgili öğretim etkinliklerinin kurgusu ile ilgili kullanılan terimler ve son olarak ders kitaplarının tümü yazar ve anlatıcı karmaşası açısından incelenmiştir. Bu inceleme sonucunda elde edilen veriler; önceden belirlenen temalara işlenmiş; sonuçlar yüzde, sayı ve betimsel kategorilerle ifade edilmiştir. Kategorileri destekleyen örnek veriler, metinlerden alıntı yapılarak sonuçlara eklenmiştir.

\section{Geçerlik ve güvenirlik}

Araştırmanın geçerlik ve güvenirliğini sağlamada her iki araştırmacı, farklı zamanlarda belirlenen öyküleyici metinlerin üzerinde araştırmanın alt sorunlarıyla ilgili tarama yapmış ve elde edilen verileri kaydetmiştir. Her iki araştırmacının yaptığı analiz bulguları, ortak bir yer ve zamanda karşılaştırıldığında elde edilen verilerde \%9o oranında görüş birliğinin olduğu ortaya çıkmıştır. Miles ve

\footnotetext{
\begin{tabular}{r|l} 
Adres & Address \\
RumeliDE Dil ve Edebiyat Araştırmaları Dergisi & RumeliDE Journal of Language and Literature Studies
\end{tabular} Osmanağa Mahallesi, Mürver Çiçeği Sokak, No:14/8 $\quad$ Osmanağa Mahallesi, Mürver Çiçeği Sokak, No:14/8 Kadıköy - ISTANBUL / TURKIYE 34714 Kadıköy - ISTANBUL / TURKEY 34714 e-posta: editor@rumelide.com e-mail: editor@rumelide.com, tel: +90 505 7958124, +90 2167730616 phone: +90 505 7958124, +90 2167730616
} 
Huberman'a göre (1994) bu oran geçerlik ve güvenirlik için uygundur. Görüş ayrılı̆̆ının ya da kararsızlı̆̆ın olduğu verilerde ise öyküleyici metinlerde aranan özellikler birlikte değerlendirilmiş ve alınan ortak karar ilgili kategoriye kaydedilmiştir.

\section{Bulgular}

Birinci alt soruna ilişkin bulgular: MEB ve özel yayınevlerinin ortaokul Türkçe ders kitaplarında yer alan öyküleyici metinlerin anlatıcı türleri ve odaklayım dağılımıyla ilgili bulgular tablolarda sunulmuştur.

Tablo 2. MEB Yayınevi ortaokul Türkçe ders kitapları öyküleyici metinlerinin odaklayım biçimleri ve anlatıcı türlerinin dağılımı

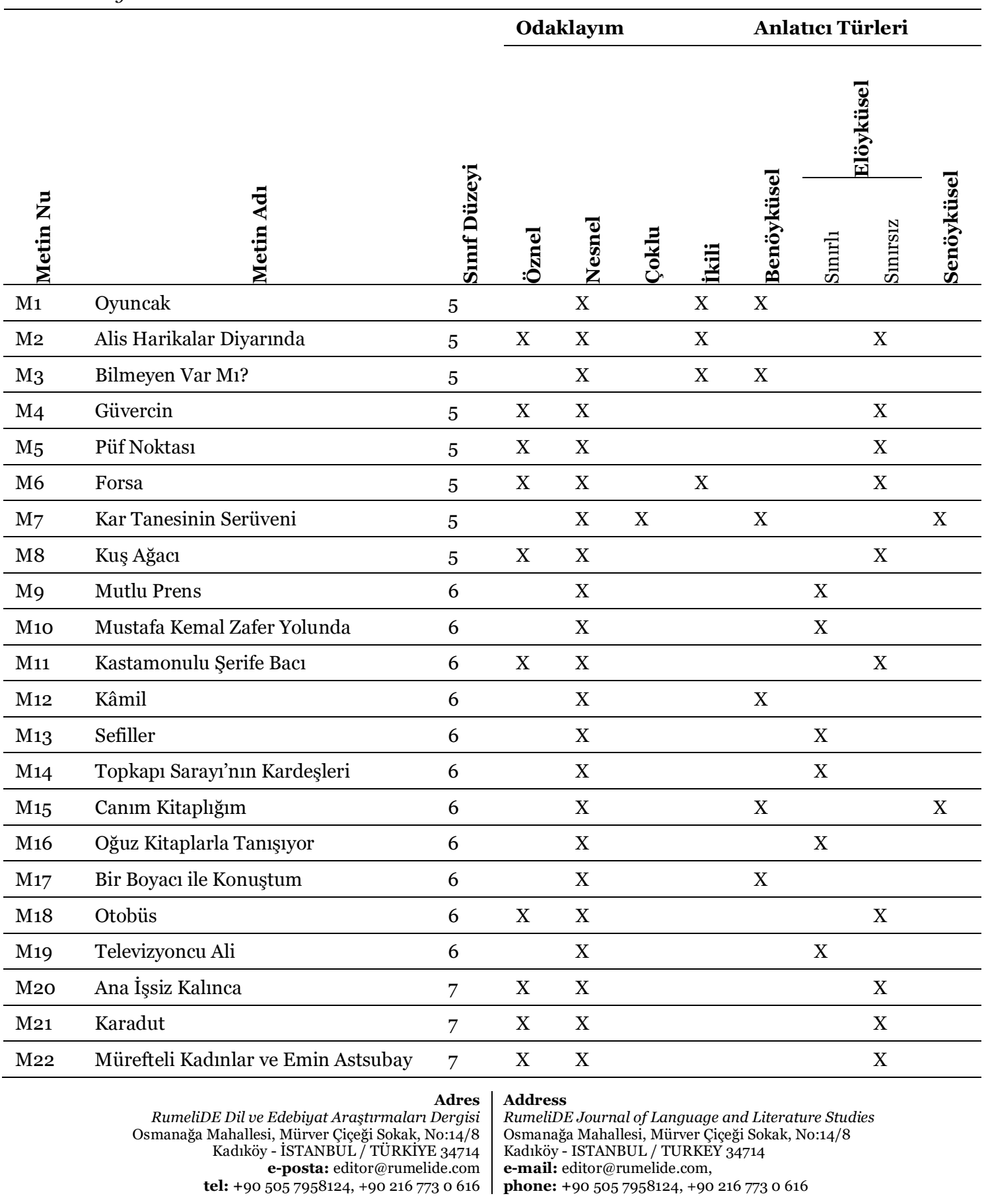




\begin{tabular}{|c|c|c|c|c|c|c|c|c|c|c|}
\hline M23 & Sığırtmaç Mustafa’nın Öyküsü & 7 & $\mathrm{X}$ & $\mathrm{X}$ & & & & & $\mathrm{X}$ & \\
\hline M24 & Penceresi Sonsuzluğa Açılan Oda & 7 & $\mathrm{X}$ & $\mathrm{X}$ & & & & & $\mathrm{X}$ & \\
\hline M25 & Okumak Düşünmek İçindir & 7 & & $\mathrm{X}$ & & & & $\mathrm{X}$ & & \\
\hline M26 & Tahta Bisiklet & 7 & & $\mathrm{X}$ & & & $\mathrm{X}$ & & & \\
\hline M27 & Kaplumbağayla İki Ördek & 7 & & $\mathrm{X}$ & & & & $\mathrm{X}$ & & \\
\hline M28 & Kızgın Bir Lira & 7 & & $\mathrm{X}$ & & & $\mathrm{X}$ & & & \\
\hline M29 & Akıllı Evlat & 7 & & $\mathrm{X}$ & & & & $\mathrm{X}$ & & \\
\hline M30 & Adını Göklere Yazdıran Çocuk & 7 & & $\mathrm{X}$ & & & & $\mathrm{X}$ & & \\
\hline M31 & “A” Harfi & 7 & & $\mathrm{X}$ & & & $\mathrm{X}$ & & & \\
\hline M32 & İki Dost Bir Kuş & 7 & & $\mathrm{X}$ & & & & $\mathrm{X}$ & & \\
\hline M33 & Yusufçuk & 7 & & $\mathrm{X}$ & & & & $\mathrm{X}$ & & $\mathrm{X}$ \\
\hline M34 & Broşür & 7 & $\mathrm{X}$ & $\mathrm{X}$ & & & & & $\mathrm{X}$ & \\
\hline M35 & Ağaçtan Oyma Su Tası & 7 & & $\mathrm{X}$ & & $\mathrm{X}$ & $\mathrm{X}$ & & & \\
\hline M36 & Kaşağ & 8 & $\mathrm{X}$ & $X$ & & $\mathrm{X}$ & $\mathrm{X}$ & & & \\
\hline M37 & Kedi ile Fare & 8 & $\mathrm{X}$ & $\mathrm{X}$ & & & & & $\mathrm{X}$ & \\
\hline M38 & Kınalı Ali & 8 & & $\mathrm{X}$ & & & & $\mathrm{X}$ & & \\
\hline M39 & Uzay Giysileri & 8 & & $\mathrm{X}$ & & & & $\mathrm{X}$ & & $\mathrm{X}$ \\
\hline M40 & Portakal & 8 & $\mathrm{X}$ & $\mathrm{X}$ & & & $\mathrm{X}$ & & & \\
\hline M41 & Robinson Crusoe & 8 & & $\mathrm{X}$ & & & & $\mathrm{X}$ & & \\
\hline M42 & Göç Destanı & 8 & & $\mathrm{X}$ & & & & $\mathrm{X}$ & & \\
\hline M43 & Kız Kulesi & 8 & & $\mathrm{X}$ & & & & $\mathrm{X}$ & & \\
\hline M44 & Yllkı Atı & 8 & & $\mathrm{X}$ & & & & $\mathrm{X}$ & & \\
\hline M45 & Gündüzünü Kaybeden Kuş & 8 & & $\mathrm{X}$ & & & $\mathrm{X}$ & $\mathrm{X}$ & & \\
\hline M46 & Haritada Bir Nokta & 8 & & $\mathrm{X}$ & & $\mathrm{X}$ & $\mathrm{X}$ & & & \\
\hline M47 & Kalbim Rumeli'de Kaldı & 8 & & $\mathrm{X}$ & & $\mathrm{X}$ & & $\mathrm{X}$ & & \\
\hline \multicolumn{2}{|c|}{ Toplam n } & & 16 & 47 & 1 & 8 & 14 & 20 & 14 & 4 \\
\hline
\end{tabular}

Bu sonuçlara göre MEB ortaokul Türkçe ders kitaplarında bulunan öyküleyici metinlerin tamamında nesnel odaklayım; 16 metinde öznel odaklayım, 8 metinde ikili odaklayım ve sadece 1 metinde çoklu odaklayım kullanılmıştır.

MEB yayınevinin ortaokul Türkçe ders kitaplarında bulunan öyküleyici metinlerde en fazla elöyküsel anlatım türü kullanılmış, bu anlatım türünün farkhı bir biçimi olan sınırlı elöyküsel anlatım türü en fazla kullanılmıştır. Benöyküsel anlatıcı 14 metinde kullanılırken senöyküsel anlatıcı ise sadece 4 metinde kullanılmıştır. Benöyküsel ve senöyküsel 2 metinde; elöyküsel ve senöyküsel 2 metinde; benöyküsel ve elöyküsel anlatıcı türleri ise 1 metinde birlikte kullanılmıştır.

Odaklayım biçimleri ve anlatıcı türleri için aşağıdaki örnekler verilebilir:

"Kızımla iki torunumun evden çıkmasım bekliyorum. Pencereden dışarı bakıyorum, onlar gözden kayboluncaya kadar. Sonra hemen torunlarımın odasına giriyorum, dolabı açıyorum. En sevdiğim,

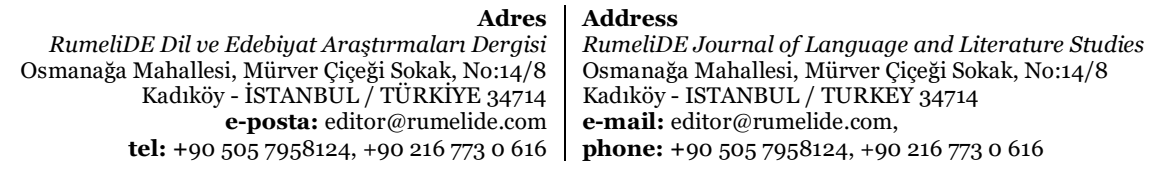


elektrikli tren.” (Oyuncak, 5. sınıf Türkçe ders kitabı, 2017, s. 10; nesnel ve ikili odaklayım, benöyküsel anlatıcı).

"Bütün bunlar düşününce gayrete geliyorlar, buz tutan yollarda kafileler hâlinde ilerlemeye çalışıyorlardı. Dağlık ve ormanlık yollardan geçerken kurtların seslerini duyuyor, kendilerine saldırmalarından korkuyorlardı. Cephaneler, sabahın erken vakitlerinde kağnılara yükleniyordu. Kağnılar yüklerini alnca hiç beklemeden yola koyuluyorlardı.” (Kastamonulu Şerife Bacı, 6. sınıf Türkçe ders kitabı, 2017, s. 50; öznel ve nesnel odaklayım, sınırsız elöyküsel anlatıcı)

"Emin Bey, Serpil Hanım’n hüzünlü hâlinden çok etkilenmişti. Özellikle (...) gözlerindeki derin hüzün onu daha da üzmüştü. Dışarıdan sık sık top sesleri geliyordu. Oysa burası cepheye çok uzaktı. (Mürefteli Kadınlar ve Emin Astsubay, 7. sınıf Türkçe ders kitabı, 2018, s. 46; öznel ve nesnel odaklayım, sinırsız elöyküsel anlatıcı).

"Ahırın avlusunda oynarken aşağıda, gümüş söğütler altında görünmeyen derenin hazin şırlltısını işitirdik. Evimiz iç çitin büyük kestane ağaçları arkasında kaybolmuş gibiydi. Annem, İstanbul'a gittiği için benden bir yaş küçük olan kardeşim Hasan’la artık Dadaruh'un yanından hiç ayrlmıyorduk. Bu, babamin seyisi, ihtiyarca bir adamdı. Sabahleyin erkenden ahra koşuyorduk." (Kaşağı, 8. sınıf Türkçe ders kitabı, 2019, s.20; öznel, nesnel ve ikili odaklayım; benöyküsel anlatıcı).

Tablo 3. Özel Yayınevleri ortaokul Türkçe ders kitapları öyküleyici metinlerinin odaklayım biçimleri ve anlatıcı türlerinin dağılımı

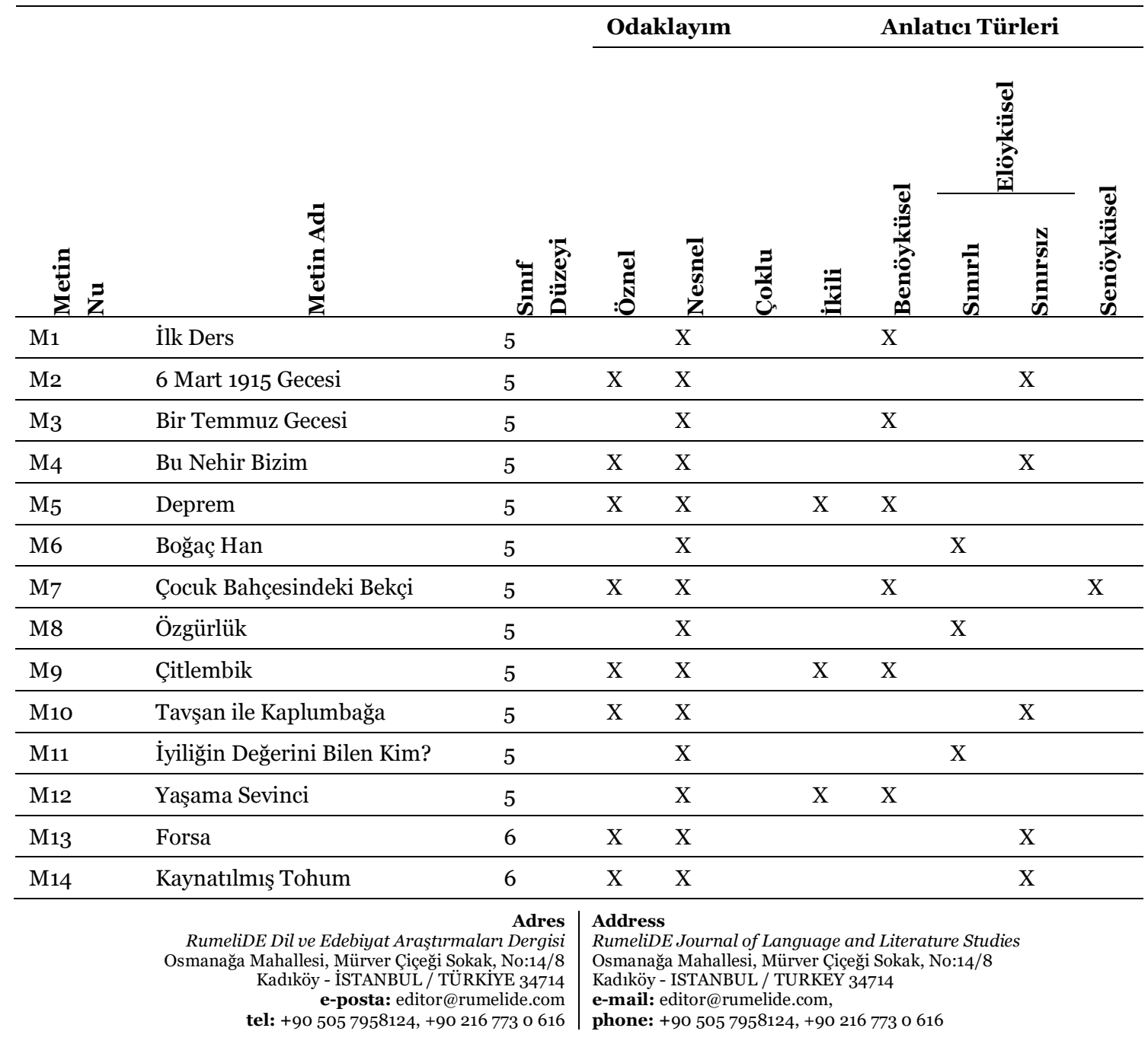




\begin{tabular}{|c|c|c|c|c|c|c|c|c|c|c|}
\hline M15 & Ceylana Yardım Edenler & 6 & $\mathrm{X}$ & $\mathrm{X}$ & & & $X$ & & $\mathrm{X}$ & \\
\hline M16 & $\begin{array}{l}\text { Boş Bir Kümes, Birkaç Dolu } \\
\text { Kalp }\end{array}$ & 6 & $\mathrm{X}$ & $\mathrm{X}$ & & & & & $\mathrm{X}$ & \\
\hline M17 & Atatürk Orman Çiftliği & 6 & $\mathrm{X}$ & $\mathrm{X}$ & & & & & $\mathrm{X}$ & \\
\hline M18 & Nasrettin Hoca Fikraları & 6 & & $\mathrm{X}$ & & & & $\mathrm{X}$ & & \\
\hline M19 & Ben Kimim? & 6 & $\mathrm{X}$ & $\mathrm{X}$ & & & & & $\mathrm{X}$ & \\
\hline M2O & Ömür Törpüsü & 6 & $\mathrm{X}$ & $\mathrm{X}$ & & & & & $\mathrm{X}$ & \\
\hline M21 & Sihirli Pasta & 6 & & $\mathrm{X}$ & & & $\mathrm{X}$ & & & \\
\hline M22 & Beyaz Diş & 6 & $\mathrm{X}$ & $\mathrm{X}$ & & & & & $\mathrm{X}$ & \\
\hline M23 & Robotik ile Enerji & 6 & & $\mathrm{x}$ & & & & $\mathrm{X}$ & & \\
\hline M24 & Karanfiller ve Domates Suyu & 7 & $\mathrm{X}$ & $\mathrm{X}$ & & & $\mathrm{X}$ & & & $\mathrm{X}$ \\
\hline M25 & Ninenin Kitabı & 7 & & $\mathrm{X}$ & & & & $\mathrm{X}$ & & \\
\hline M26 & Akıllı Kız & 7 & & $\mathrm{X}$ & & & & $\mathrm{x}$ & & \\
\hline M27 & Koca Seyit & 7 & & $\mathrm{X}$ & & & & $\mathrm{X}$ & & \\
\hline M28 & Meşe ile Saz & 7 & & $\mathrm{x}$ & & & & $\mathrm{X}$ & & \\
\hline M29 & Küçük Çocuk & 7 & $\mathrm{X}$ & $\mathrm{X}$ & & & & & $\mathrm{X}$ & \\
\hline M30 & Sözcüklerin Gücü & 7 & $\mathrm{X}$ & $\mathrm{X}$ & & & & & $\mathrm{X}$ & \\
\hline $\mathrm{M}_{31}$ & Büyük Mimar Koca Sinan & 7 & & $\mathrm{X}$ & & & & $\mathrm{X}$ & & \\
\hline M32 & Küçük Yunus & 7 & $\mathrm{X}$ & $\mathrm{X}$ & & & & & $\mathrm{X}$ & $\mathrm{X}$ \\
\hline M33 & Son Leylek & 7 & $\mathrm{X}$ & $\mathrm{x}$ & & $\mathrm{X}$ & $\mathrm{X}$ & & & \\
\hline M34 & Karamsar ve İyimser Bakış Açısı & 7 & & $\mathrm{X}$ & & & & $\mathrm{x}$ & & \\
\hline M35 & Ampülün İlk Yanışı & 7 & $\mathrm{X}$ & $\mathrm{x}$ & & & & & $\mathrm{X}$ & \\
\hline M36 & Bilgin ile Hoca & 8 & & $\mathrm{X}$ & & & & $\mathrm{X}$ & & \\
\hline M37 & Oğuz Kağan Destanı & 8 & & $\mathrm{X}$ & & & & $\mathrm{X}$ & & \\
\hline M38 & Garip Bir Hediye & 8 & $\mathrm{X}$ & $\mathrm{X}$ & & & & & $\mathrm{X}$ & \\
\hline M39 & Dokuzuncu Hariciye Koğuşu & 8 & $\mathrm{X}$ & $\mathrm{X}$ & & $\mathrm{X}$ & $\mathrm{X}$ & & & \\
\hline M40 & Karanfiller ve Domates Suyu & 8 & $\mathrm{X}$ & $\mathrm{X}$ & & & $\mathrm{X}$ & & & $\mathrm{X}$ \\
\hline Toplam n & & & 24 & 41 & $\mathrm{o}$ & 6 & 13 & 13 & 16 & 4 \\
\hline
\end{tabular}

Bu sonuçlara göre özel yayınevlerinin ortaokul Türkçe ders kitaplarında bulunan öyküleyici metinlerin tamamında nesnel odaklayım kullanılmış; 24 metinde öznel odaklayım, 6 metinde ikili odaklayım tercih edilmiştir; hiçbir metinde çoklu odaklayım kullanılmamıştır. Özel yayınevlerinin ortaokul Türkçe ders kitaplarında bulunan öyküleyici metinlerde en fazla elöyküsel anlatım türü kullanılmış, bu anlatım türünün farklı bir şekli olan sınırsız elöyküsel anlatım türü en fazla kullanılmıştır. Benöyküsel anlatıcı 13 metinde kullanılırken senöyküsel anlatıcı ise sadece 4 metinde kullanılmıştır. Benöyküsel ve senöyküsel 3 metinde; elöyküsel ve senöyküsel 1 metinde; benöyküsel ve elöyküsel anlatıcı türleri ise 1 metinde birlikte kullanılmıştır.

Odaklayım biçimleri ve anlatıcı türleri için aşağıdaki örnekler verilebilir:

"Müthiş bir heyecan ve endişe vard. Ya Nusrat, düşman gemilerince fark edilirse? İşte, tam anlamıla felaket olurdu. Vatanın selameti bu maymlarm denize dökülmesine bağhydı. Bu işin sessizce

Adres

RumeliDE Dil ve Edebiyat Araştırmaları Dergisi Osmanağa Mahallesi, Mürver Çiçeği Sokak, No:14/8 Kadıköy - ISTANBUL / TÜRKIYE 34714 e-posta: editor@rumelide.com tel: +90 $5057958124,+902167730616$
Address

RumeliDE Journal of Language and Literature Studies

Osmanağa Mahallesi, Mürver Çiçeği Sokak, No:14/8

Kadıköy - ISTANBUL / TURKEY 34714

e-mail: editor@rumelide.com,

phone: +90 505 7958124, +90 2167730616 
başarlması gerekiyordu. Herkes heyecanlıydı ve korkuyordu. Nihayet istedikleri hedefe gelmişlerdi." (6 Mart 1915 Gecesi, 5. sınıf Türkçe ders kitabı, 2019, s. 53; öznel ve nesnel odaklayım; sınırsız elöyküsel anlatıc1).

“Gemisi altın, gümüş, inci, elmas, esir dolu vatana dönerken kenarsız denizin ortasında evlenmiş; oğlu Turgut Çanakkale'yi geçerken doğmuştu. Şimdi kırk beş yaşında olmalıydı. Acaba yaşıyor muydu? Hayalini unuttuğu karısı acaba hâlâ să̆ mıydı? Kırk senedir İstanbul'un minareli ufku hayalinden hiç silinmemiş̧i. "Bir gemim olsa gözümü kapar, Kabataş’n önüne demir atarım.” diye düşünürdü. Altmış yaşın geçtikten sonra efendisi onu, sözde serbest brraktı. Bu, serbest burakmak değil; sokağa, açh̆ğa, perişanlığa atmaktı.” (Forsa, 6. sınıf Türkçe ders kitabı, 2018, s. 12; öznel ve nesnel odaklayım, sınırsız elöyküsel anlatıcı).

"İşte böyle bir yerde köyün insanların düşünüyorum. Kitaplar, bir zaman bana, insanlar sevmek lazım geldiğini, insanları sevince tabiatın, tabiatı sevince dünyanın sevileceğini oradan yaşama sevinci duyulacağımı öğretmiştiler. Hayır, şimdi insanları kitapları öğrettiği şekilde sevmiyorum. (...) Küçük hanımlar! Bugünlerde bir gün nişanlnız size koyu al renkli karanfiller gönderecektir. Dikkat edin, belki Mustafa'nınkilerdir. Küçük beyler! Domatesler göreceksiniz çarşıda.” (Karanfiller ve Domates Suyu, 7. sınıf Türkçe ders kitabı, 2019, s.10-13; öznel ve nesnel odaklayım, benöyküsel ve senöyküsel anlatııı).

"Bir ağaç altına oturdum ve hasta dizimin açısını her vakit ki itina ile ayarlayarak bacağımı uzattım. Bu zavall uzvumun talihine ait hiçbir şey düşünmek istemiyordum, şuurumun hastahğım üstüne boşaltacağı aydınlıktan kaçmak için ruhumun daha karanlık ve izbe hatlarma kendimi atıyor, daha korkunç ve karışık hayallere dalıyordum.” (Dokuzuncu Hariciye Koğuşu, 8. sinıf Türkçe ders kitabı, 2014, s. 95; öznel, nesnel ve ikili odaklayım, benöyküsel anlatıcı).

İkinci alt soruna ilişkin bulgular: Bu sorunun çözümlenmesinde Ortaokul Türkçe ders kitaplarında öyküleyici metinlerle ilgili öğretim etkinlikleri incelenmiş ve anlatıcıyla ilgili öğretim etkinliklerinin sınıf seviyelerine göre yayınevlerinde dağılımı belirlenmiştir.

Tablo 4. Anlatıcı kavramının sınıf seviyelerine göre MEB yayınevinde dağılımı

\begin{tabular}{|c|c|c|c|c|c|}
\hline $\begin{array}{l}\text { Sinıf ve } \\
\text { Metin nu }\end{array}$ & Metin adı & Tür & $\begin{array}{l}\text { Anlatıcı } \\
\text { etkinliği }\end{array}$ & $\mathbf{f}$ & $\%$ \\
\hline $5 / 1$ & Oyuncak & Öykü & - & \multirow{8}{*}{$1 / 8$} & \multirow{8}{*}{12} \\
\hline 2 & Alis Harikalar Diyarında & Roman & - & & \\
\hline 3 & Bilmeyen Var mi? & Öykü & - & & \\
\hline 4 & Güvercin & Fabl & - & & \\
\hline 5 & Püf Noktası & Öykü & 1 & & \\
\hline 6 & Forsa & Öykü & - & & \\
\hline 7 & Kartanesinin Serüveni & Öykü & - & & \\
\hline 8 & Kuş Ağacı & Masal & - & & \\
\hline $6 / 1$ & Mutlu Prens & Roman & & \multirow{4}{*}{$3 / 11$} & \multirow{4}{*}{27} \\
\hline 2 & Mustafa Kemal Zafer Yolunda & Öykü & 1 & & \\
\hline 3 & Kastamonulu Şerife Bacı & Öykü & - & & \\
\hline \multirow[t]{2}{*}{4} & Kâmil & Öykü & - & & \\
\hline & $\begin{array}{r}\text { Adres } \\
\text { RumeliDE Dil ve Edebiyat Arassttrmaları Dergisi } \\
\text { Osmanağa Mahallesi, Mürver Ciçeği Sokak, No:14/8 } \\
\text { Kadıköy - İSTANBUL / TÜRKIYE 34714 } \\
\text { e-posta: editor@rumelide.com } \\
\text { tel: +990 505 7958124, +90 } 216773 \text { o } 616\end{array}$ & \multicolumn{4}{|c|}{$\begin{array}{l}\text { Address } \\
\text { RumeliDE Journal of Language and Literature Studies } \\
\text { Osmanağa Mahallesi, Mürver Cicceği Sokak, No:14/8 } \\
\text { Kadıköy - ISTANBUL/TURKEY } 34714 \\
\text { e-mail: editor@rumelide.com, } \\
\text { phone: +90 505 7958124, +90 } 216773 \text { o } 616\end{array}$} \\
\hline
\end{tabular}




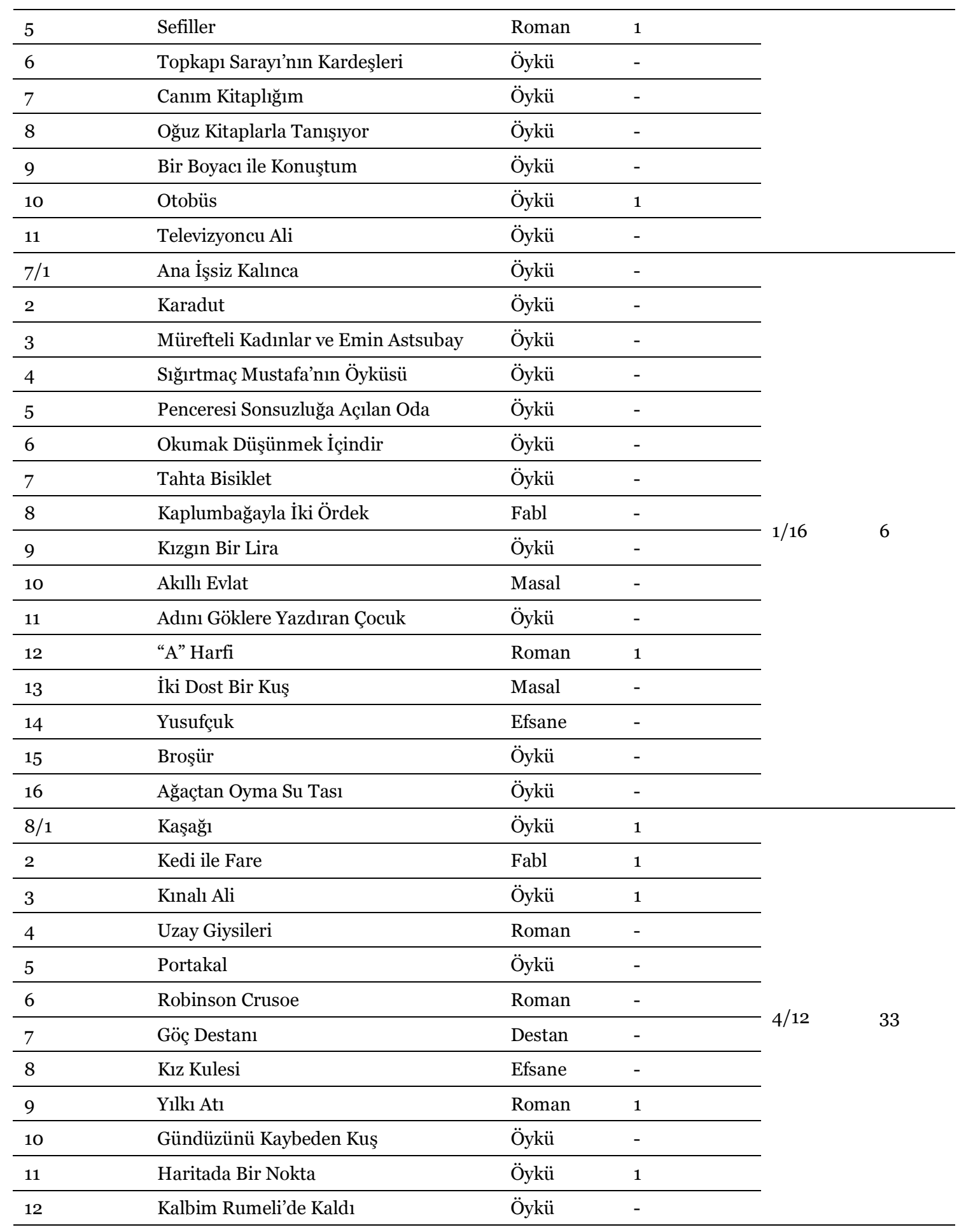

Tabloda görüldüğü gibi 5. sınıf Türkçe ders kitaplarında bulunan 8 öyküleyici metnin 1’inde; 6 . sınıf Türkçe ders kitaplarında bulunan 11 öyküleyici metnin 3'ünde; 7. sınıf Türkçe ders kitaplarında bulunan 16 öyküleyici metnin 1'inde; 8. sınıf Türkçe ders kitaplarında bulunan 12 öyküleyici metnin 4’ünde anlatıcı ile ilgili etkinlik olduğu belirlenmiştir. Bu sonuçlara göre MEB'e ait ortaokul ders kitaplarında

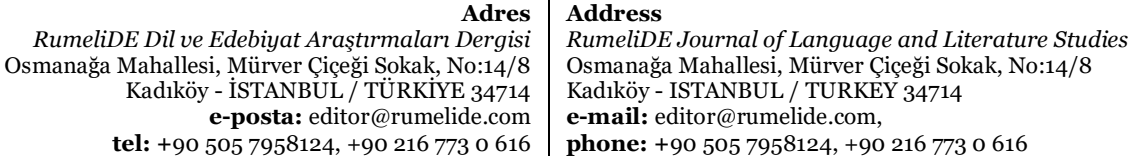


anlatıcı kavramına yer verilme oranı 5. sinıfta \%12; 6. sinıfta \%27; 7. sinıfta \%6; 8. sinıfta ise \%33 olarak gerçekleşmiştir. Bu bağlamda MEB yayınevi Türkçe ders kitaplarında anlatıcı ile ilgili öğretim etkinliklerine yer verilmesinde bir tutarsızlık olduğu görülmüştür.

Tablo 5. Anlatıc kavramının sınıf seviyelerine göre özel yayınevlerinde dağılımı

\begin{tabular}{|c|c|c|c|c|c|}
\hline $\begin{array}{l}\text { Sinıf ve } \\
\text { Metin nu }\end{array}$ & Metin adı & Tür & $\begin{array}{l}\text { Anlatici } \\
\text { etkinliği }\end{array}$ & $\mathbf{f}$ & $\%$ \\
\hline $5 / 1$ & İlk Ders & Roman & - & \multirow{12}{*}{$-4 / 12$} & \multirow{12}{*}{33} \\
\hline 2 & 6 Mart 1915 Gecesi & Öykü & 1 & & \\
\hline 3 & Bir Temmuz Gecesi & Öykü & 1 & & \\
\hline 4 & Bu Nehir Bizim & Öykü & - & & \\
\hline 5 & Deprem & Öykü & 1 & & \\
\hline 6 & Boğaç Han & Çizgi roman & - & & \\
\hline 7 & Çocuk Bahçesindeki Bekçi & Öykü & - & & \\
\hline 8 & Özgürlük & Fabl & - & & \\
\hline 9 & Çitlembik & Öykü & - & & \\
\hline 10 & Tavşan ile Kaplumbağa & Fabl & - & & \\
\hline 11 & İyiliğin Değerini Bilen Kim? & Fabl & - & & \\
\hline 12 & Yaşama Sevinci & Öykü & 1 & & \\
\hline $6 / 1$ & Forsa & Öykü & 1 & \multirow{11}{*}{$3 / 11$} & \multirow{11}{*}{27} \\
\hline 2 & Kaynatılmış Tohum & Masal & - & & \\
\hline 3 & Ceylana Yardım Edenler & Fabl & - & & \\
\hline 4 & Boş Bir Kümes, Birkaç Dolu Kalp & Öykü & - & & \\
\hline 5 & Atatürk Orman Çiftliği & Öykü & 1 & & \\
\hline 6 & Nasrettin Hoca Fıkraları & Fikra & - & & \\
\hline 7 & Ben Kimim? & Fabl & - & & \\
\hline 8 & Ömür Törpüsü & Öykü & 1 & & \\
\hline 9 & Sihirli Pasta & Öykü & - & & \\
\hline 10 & Beyaz Diş & Roman & - & & \\
\hline 11 & Robotik ile Enerji & Çizgi roman & - & & \\
\hline $7 / 1$ & Karanfiller ve Domates Suyu & Öykü & 1 & \multirow{10}{*}{$3 / 12$} & \multirow{10}{*}{25} \\
\hline 2 & Ninenin Kitabı & Öykü & 1 & & \\
\hline 3 & Akıllı Kız & Masal & - & & \\
\hline 4 & Koca Seyit & Öykü & - & & \\
\hline 5 & Meşe ile Saz & Fabl & - & & \\
\hline 6 & Küçük Çocuk & Öykü & - & & \\
\hline 7 & Sözcüklerin Gücü & Öykü & - & & \\
\hline 8 & Büyük Mimar Koca Sinan & Öykü & & & \\
\hline 9 & Küçük Yunus & Öykü & - & & \\
\hline 10 & Son Leylek & Öykü & 1 & & \\
\hline & $\begin{array}{r}\text { Adres } \\
\text { RumeliDE Dil ve Edebiyat Arassttrmaları Dergisi } \\
\text { Osmanağa Mahallesi, Mürver Ciçĕgi Sokak, No:14/8 } \\
\text { Kadıköy - İSTANBUL / TÜRKIYE } 34714 \\
\text { e-posta: editor@rumelide.com } \\
\text { tel: }+90 \text { 505 7958124, +90 216 773 o } 616\end{array}$ & \multicolumn{4}{|c|}{$\begin{array}{l}\text { Address } \\
\text { RumeliDE Journal of Language and Literature Studies } \\
\text { Osmanağa Mahallesi, Mürver Ciçeği Sokak, No:14/8 } \\
\text { Kadlköy - ISTANBUL / TURKEY } 34714 \\
\text { e-mail: editor@rumelide.com, } \\
\text { phone: +90 505 7958124, +90 } 216773 \text { o } 616\end{array}$} \\
\hline
\end{tabular}




\begin{tabular}{llll}
\hline 11 & Karamsar ve İyimser Bakış Açısı & Öykü & - \\
\hline 12 & Ampülün İlk Yanışı & Öykü & - \\
\hline $8 / 1$ & Bilgin ile Hoca & Fıkra & - \\
\hline 2 & Ŏguz Kağan Destanı & Destan & - \\
\hline 3 & Garip Bir Hediye & - & \multirow{2}{*}{ o } \\
\hline 4 & Dokuzuncu Hariciye Koğuşu & Öykü & - \\
\hline 5 & Karanfiller ve Domates Suyu & Öykü & - \\
\hline
\end{tabular}

Tabloda görüldüğü gibi 5. sınıf Türkçe ders kitaplarında bulunan 12 öyküleyici metnin 4’ünde; 6. sınıf Türkçe ders kitaplarında bulunan 11 öyküleyici metnin 3’ünde; 7. sınıf Türkçe ders kitaplarında bulunan 12 öyküleyici metnin 3’ünde anlatıcı ile ilgili etkinlik bulunduğu; 8. sınıf Türkçe ders kitaplarında bulunan 5 öyküleyici metnin hiçbirinde anlatıcı ile etkinlik bulunmadığı belirlenmiştir. Bu sonuçlara göre özel yayınevlerine ait ortaokul ders kitaplarında anlatıcı kavramına yer verilme oranı 5 . sinıfta \%33; 6. sinıfta \%27; 7. sınıfta \%25; 8. sinıfta ise \%o olarak gerçekleşmiştir. Bu bağlamda özel yayınevlerine ait Türkçe ders kitaplarında anlatıcı ile ilgili öğretim etkinliklerine yer verilmesinde bir tutarsızlık olduğu görülmüştür çünkü 8. sınıfta anlatıcı kavramına hiç yer verilmemiştir.

Üçüncü alt soruna ilişkin bulgular: Bu sorunun çözümlenmesinde ortaokul Türkçe ders kitaplarında öyküleyici metinlerle ilgili öğretim etkinlikleri incelenerek bu etkinliklerin kurgusu ve bunlarda kullanılan terimler belirlenmiştir.

MEB Yayınevi ortaokul Türkçe ders kitaplarında anlatıcı ile ilgili kurgulanan öğretim etkinliklerine ilişkin bulgular: MEB ortaokul Türkçe ders kitapları incelendiğinde; anlatıcı ile ilgili öğretim etkinlikleri dört farklı grupta toplanabilir. Birinci grupta anlatıcı kavramına "olay, yer, zaman, kahramanlar ve anlatıcı şeklinde hikâyenin unsurları" arasında yer verilmiştir. İkinci grup etkinliklerde ise "metin türüyle ilgili etkinlikler içerisinde" doğru/yanlışşeklinde kurgulanmıştır. "Olaylar kronolojik straya uygun biçimde üçüncü kişi ağzıyla anlatılmıştır.” "A” Harfi, 7. sınıf Türkçe ders kitabı, s. 158). Üçüncü grupta ise "farkh metinlerin anlatıcıların karşılaştırma" şeklinde kurgulanmıştır. "Sefiller romanı ile Kâmil'in anlatıcısı karşılaştırma" (Sefiller, 6. sınıf ders kitabı, s. 118). "Metinleri karşılaştırma kahramanlar, konu, biçim anlatıcı vb.)” (Kedi ile Fare, 8. sınıf Türkçe ders kitabı, s. 37). Dördüncü grupta ise anlatıcı kavramıyla ilgili bağımsız etkinlikler hazırlanmıştır. "4. Etkinlik (bağımsız etkinlik): Metinde anlatım kimin ağzından yapılmıştır? Metinden aldığınız örneklerle açıklayınız. (Haritada Bir Nokta, 8. sınıf Türkçe ders kitabı, s. 258).

Özel Yayınevleri ortaokul Türkçe ders kitaplarında anlatıcı ile ilgili kurgulanan öğretim etkinliklerine ilişkin bulgular: Özel yayınevlerinin ortaokul Türkçe ders kitapları incelendiğinde; anlatıcı ile ilgili öğretim etkinlikleri iki farklı grupta toplanabilir. Birinci grupta anlatıcı kavramına "olay, yer, zaman, kahramanlar ve anlatıcı şeklinde hikâyenin unsurları” arasında yer verilmiştir. İkinci grupta ise anlatıcı kavramıyla ilgili bağımsız bir etkinlik kurgulanmıştır. "Metinden, birinci kişili anlatımın yapıldığı örnek cümleler bulup aşağıya yazını.” (Karanfiller ve Domates Suyu, 7. sınıf Türkçe ders kitabı, s. 16). Sonuç olarak; MEB yayınevinin ortaokul Türkçe ders kitaplarında anlatıcıyla ilgili kurgulanan etkinlik biçiminin özel yayınevlerinin ders kitaplarına göre daha farklı biçimde olduğu söylenebilir.

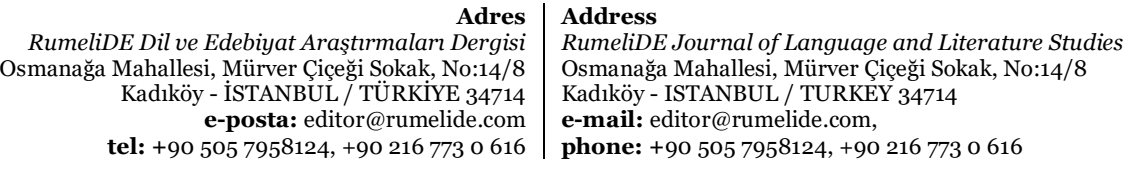

RumeliDE Journal of Language and Literature Studies

Osmanağa Mahallesi, Mürver Çiçeği Sokak, No:14/8

Kadıköy - ISTANBUL / TURKEY 34714

e-mail: editor@rumelide.com,

phone: +90 5057958124, +90 2167730616 
MEB yayınevi ortaokul Türkçe ders kitaplarında anlatıcı ile ilgili kullanılan terimlere ilişkin bulgular: İncelenen ortaokul Türkçe kitaplarında 5 ve 6 . sınıfta anlatıcı; 7. sınıfta ağız; 8. sınıfta anlatıcı ve ağız terimleri kullanılmıştır.

Özel yayınevleri ortaokul Türkçe ders kitaplarında anlatıcı ile ilgili kullanılan terimlere ilişkin bulgular: İncelenen ortaokul Türkçe ders kitaplarında 5. sınıfta anlatıcı; 6. sınıfta anlatıcı, ağız; kahraman, gözlemci, hâkim - ilahi bakış açısı; 7. sınıfta birinci kişili anlatım-üçüncü kişili anlatım terimleri kullanılmış; 8. sınıfta ise herhangi bir terim kullanılmamıştır.

Sonuç olarak; incelenen MEB ve özel yayınevlerine ait ortaokul Türkçe ders kitaplarında "anlatıcı" ile ilgili anlatıcı, 1 ve 3. tekil kişi ağzı, birinci-üçüncü kişili anlatım ve bakış açısı terimlerinin kullanıldığ ve yine her iki yayınevine ait kitaplarda terim birliğinin olmadığı gözlemlenmiştir.

Dördüncü alt soruna ilişkin bulgular: Bu sorunun çözümlenmesinde Ortaokul Türkçe ders kitaplarındaki öğretim etkinlikleri incelenmiş, yazar ve anlatıcı karmaşası bulunanlar tespit edilerek alıntılar yapılmıştır.

MEB Yayınevi ortaokul Türkçe ders kitaplarında yazar ve anlatıcı karmaşasına ilişkin bulgular: 5. sınıf Türkçe ders kitabında yazar ve anlatıcı karmaşasının bulunmadığı görülmüştür. 6 . sınıf ders kitabında ise iki metne ait etkinliklerde yazar ve benöyküsel anlatıcı karmaşasının olduğu bulgulanmıştır. Bu metinlerle ilgili hazırlanan etkinliklerde şu sorulara yer verilmiştir:

“1. Yazar, Kâmil ile karşılaşınca niçin korkmuştur?

2. Kâmil hangi amaçla yazarm evine gelmiştir?

3. Yazara göre Kâmil bahçe kapısını açmaya niçin çekinmiştir?

5. Yazarın babası, Kâmil ile niçin ilgilenmektedir?” (Kâmil, 6. simıf ders kitabı, s. 109, benöyküsel anlaticl)

"1. Yazar, kundura boyatmaya niçin alışamamıştır? Açıklayınız.

2. Yazar, boyacılarla berberleri hangi yönden karşılaştırmaktadır?

3. Boyacı, yazarın mesleğini hangi nesneleri gözlemleyerek bulmaya çalışır?” (Bir Boyacı ile Konuştum, 6. sinıf ders kitabı, s. 225, benöyküsel anlatıcı)

7. sınıf ders kitabında dört metne ait etkinliklerde yazar ile sınırsız ve sinırlı elöyküsel anlatıcı karmaşasının olduğu bulgulanmıştır. Bu metinlerle ilgili hazırlanan etkinliklerde şu sorulara yer verilmiştir:

“1. Yazar, karadut meyvesinin tadını nasıl anlatıor?” (Karadut, 7. Sinıf ders kitabı, s. 29, sinırsız elöyküsel anlatıcı).

“1. Yazar, Atatürk’ün Dolmabahçe Sarayı’nda yattı̆̆ı odayı nasıl anlatmıştır?” (Penceresi Sonsuzluğa Açılan Oda, 7. sınıf ders kitabı, s. 61, sinursız elöyküsel anlatıcı)

“2. Yazarın okumak ile düşünmek arasında kurduğu bağlantıya katılıp katılmadığınızı nedenleriyle anlatinzz.

4. Yazarın bilim adamları ile "düşünmek" hakkındaki görüşlerini nasıl değerlendiriyorsunuz?

5. Yazarm sağhklı beyin ve düşünme eylemiyle ilgili görüşlerine katılyor musunuz? Neden?” (Okumak Düşünmek İçindir, 7.sınıf ders kitabı, s. 88, sinırl elöyküsel anlatıcı)

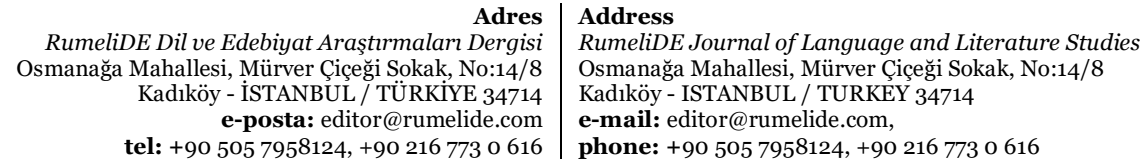


8. sınıf ders kitabında üç metne ait etkinliklerde yazar ile benöyküsel anlatıcı ve sınırlı elöyküsel anlatıcı karmaşasının olduğu bulgulanmıştır. Bu metinlerle ilgili hazırlanan etkinliklerde şu sorulara yer verilmiştir:

"1. Yazarın aile ortamı nasıldır? Kendi aile ortamınızla karşılaştırıız.

2. Yazarın yatıl okula gitmesine kim karar veriyor? Niçin?

3. Yazar yatılı okulda en çok neye şaşırıyor?

4. Yazarın ilk defa yatılı okulda gördüğ̈̈ yiyecek hangisidir? Yazar bu yiyeceğin tadını beğeniyor mu?

5. Yazar ne zaman köyüne gidiyor? Giderken annesine ve kardeşine ne götürüyor?” (Portakal, 8. sinif ders kitabl, s. 126, benöyküsel anlatıci).

"1. Yazar metinde hangi tür martılardan söz ediyor? Sözü edilen martıyı hiç duydunuz mu?

5. "Miho hâlâ gündüzü arıyor ama bulamıyordu." ifadesiyle yazarn anlatmak istediği ne olabilir?" (Gündüzünü Kaybeden Kuş, 8. simıf ders kitabı, s. 236-237, benöyküsel-sınırh elöyküsel anlatıcı).

"1. Yazar adaları niçin seviyor olabilir?

2. Yazar adadaki yaşamın nasll sürdürmek istiyor? Sizce bu kararı almasında neler etkili olmuştur?

6. Yazar, tanık olduğu haksızlk karşısında ne yapıyor?” (Haritada Bir Nokta, 8. sinıf ders kitabı, s. 256-257, benöyküsel anlatıcı).

Özel Yayınevleri ortaokul Türkçe ders kitaplarında yazar ve anlatıcı karmaşasına ilişkin bulgular: 5. sınıf Türkçe ders kitabında beş metne ait etkinliklerde yazar ve anlatıcı karmaşasının olduğu bulgulanmıştır. Buna göre alıntılarda görüldüğü gibi metinlerle ilgili hazırlanan sorularda yazar ile benöyküsel, senöyküsel ve ikili anlatıı karmaşasının olduğu gözlemlenmiştir. Bu metinlerle ilgili hazırlanan etkinliklerde şu sorulara yer verilmiştir:

“4. Yazarm okulla ilgili anısını anlatmasmın sebebi nedir?

5. Munise, yazarı hangi yönden etkilemiştir?” (İlk Ders, 5. Sinff ders kitabı, s. 28, benöyküsel anlatıcl)

"1. Yazarın babası deprem sirasında ne yapmıştır?

2. Yazarın babasıyla gurur duymasını sağlayan olay nedir?

3. Deprem sonrasında yazar ve ailesi nerede kalmıştır?

4. Yazarın babasını böyle bir felaket sonrasında diğer insanlarm yardımına gitmesini nasıl değerlendirirsiniz? Arkadaşlarmızla tartışını.” (Deprem, 5. sinıf ders kitabı, s. 88, ikili ve benöyküsel anlatıcı)

"1. Yazar, çocuk parkını nasıl betimlemiştir?

3. Yazar, neden bekçinin olmadığı saatlerde parka gitmektedir?

5. Yazar, bekçiye neden hak vermiştir?” (Çocuk Bahçesindeki Bekçi, 5. sınıf ders kitabı, s. 140, ben ve senöyküsel anlatıcı)

“4. Süleyman'a Hasan ve yazar nasıl müdahale etmiştir?

6. Süleyman, Hasan ve yazara niçin teşekkür ediyor? Siz böyle bir durum karşısında neler düşünürdünüz? (Çitlembik, 5. sinff ders kitabl, s. 175, ikili ve benöyküsel anlatıc).

"1. Yaşama Sevinci” adlı metindeki anlatıcını ve Münevver teyzenin yerinde siz olsaydınz neler hissederdiniz? Yazmız.

2. Yazar, Münevver teyze için nasıl bir iyilikte bulunuyor?

3. Anlatıcını çözümü nedir?” (Yaşama Sevinci, 5. sınff ders kitabı, s. 208-209, ikili ve benöyküsel anlatıci)

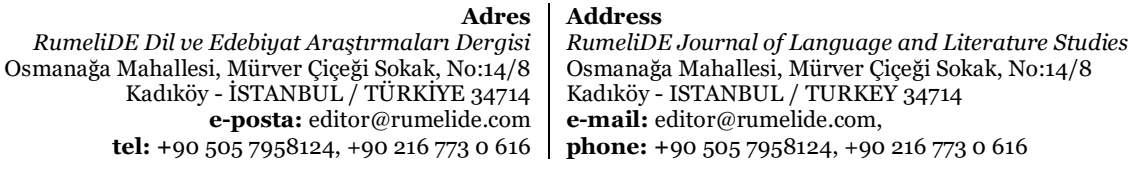


6. sınıf Türkçe ders kitabında bir metne ait etkinliklerde yazar ve sınırsız elöyküsel anlatıcı karmaşasının olduğu bulgulanmıştır. Bu metinle ilgili hazırlanan etkinlikte şu sorulara yer verilmiştir:

"8. Yazar, Beyaz Diş’in eski yaşamıyla yeni yaşamının niçin birbirinin karşıtı olduğunu düşünüyor olabilir?”(Beyaz Diş, 6 .sınıf ders kitabı, s. 231, sınırsız elöyküsel anlatıcı)

7. sınıf ders kitabında bir metne ait etkinliklerde yazar ile ben ve senöyküsel anlatıcı karmaşasının olduğu bulgulanmıştır. Bu metinle ilgili hazırlanan etkinlikte şu sorulara yer verilmiştir:

“1. Kitaplar bir zamanlar yazara neler öğretmiş?

3. Kör Mustafa’nın görmeyen gözü yazara neyi hatırlatmış?

5. Yazarm köyünde hangi ağaçlar yetişirmiş?

8. Yazarm, Mustafa'yı takdir etmesinin nedeni nedir?” (Karanfiller ve Domates Suyu, 7. Sinıf ders kitabı, s. 15, ben ve sen öyküsel anlatıcı).

İncelenen 8. sınıf Türkçe ders kitabında ise yazar ve anlatıcı karmaşasının bulunmadığı görülmüştür, ayrıca bu kitapta metin içi soruların olmadığı ve anlatıcı ile ilgili hiçbir etkinliğin olmadı̆̆ı gözlemlenmiştir. Yazar ve anlatıı karmaşasının bulunmama sebebi bu durum olabilir. Sonuç olarak; incelenen ortaokul Türkçe ders kitaplarında MEB 5. sınıf ve özel yayınevi 8. sınıf ortaokul Türkçe ders kitaplarında yazar ve anlatıcı karmaşasının bulunmadığı, buna karşın her iki yayınevinin bütün sınıf düzeylerinde bu karmaşanın bulunduğu gözlemlenmiştir.

\section{Tartışma ve sonuç}

Ortaokul Türkçe ders kitapları öyküleyici metinlerinde kullanılan anlatıcı tür ve odaklayım biçimlerinin sergilediği görünümün belirlendiği bu araştırmadan elde edilen sonuçlar, daha önce yapılan alanyazın araştırmaları sonuçlarıyla birleştirilip tartışlacaktır.

$\mathrm{Bu}$ araştırma sonuçlarına göre her iki yayınevinin incelenen öyküleyici metinlerinde en fazla nesnel odaklayımın, ikinci sırada ise öznel odaklayımın bulunduğu gözlemlenmiştir. Araştırmada ikili odaklayımın; MEB ortaokul Türkçe ders kitaplarındaki sekiz öyküleyici metinde ve özel yayınevlerindeki altı metinde bulunduğu belirlenmiştir. Ayrıca MEB ortaokul Türkçe ders kitaplarında yer alan sadece bir metinde çoklu odaklayımın tercih edildiği, özel yayınevlerinde yer alan öyküleyici metinlerin hiçbirinde çoklu odaklayımın tercih edilmediği görülmüştür. Bu sonuçlara göre her iki yayınevinin öyküleyici metinlerinin odaklayım biçimlerinin dağılımının birbirine benzediği söylenebilir.

Daha önce yapılan araştırmalarda ders kitaplarında en fazla nesnel ve ardından öznel odaklayım biçiminin kullanıldığı belirlenmiştir (Ercantürk, 2015; Şen, 2020). Ercantürk (2015) incelediği 9 metinde nesnel odaklayım, 4 metinde ise öznel odaklayım kullanıldığını belirlemiştir. Şen (2020) örneklem aldığı bütün metinlerde nesnel odaklayımın bulunduğunu, ancak öznel odaklayımın daha seyrek kullanıldığını tespit etmiştir. Alanyazından belirlenen araştırma sonuçlarıyla örtüşen şekilde bu araştırma sonuçlarına göre; her iki yayınevinin incelenen öyküleyici metinlerinde en fazla nesnel odaklayımın bulunduğu, ikinci sırada ise öznel odaklayımın bulunduğu gözlemlenmiştir. Buna göre ortaokul Türkçe ders kitapları öyküleyici metinlerinde anlatıcıların genelde olayların dışında konumlanarak olayları gözlemledikleri söylenebilir. Şen'e göre (2020) bu durumun baskın olması; anlatıcının okur üzerinde baskı kurmak isteyen bir yetişkin işlevi üstlenmesine neden olur ve yetişkin anlatıcılar ayrıcalıklı bir konuma sahip olur. Buna karşın Sinan ve Demir (2011) inceledikleri metinlerin çoğunluğunda öznel odaklayım kullanıldığını gözlemlemiştir. Her şeyi görüp bilen soyut bir göz, tanrısal

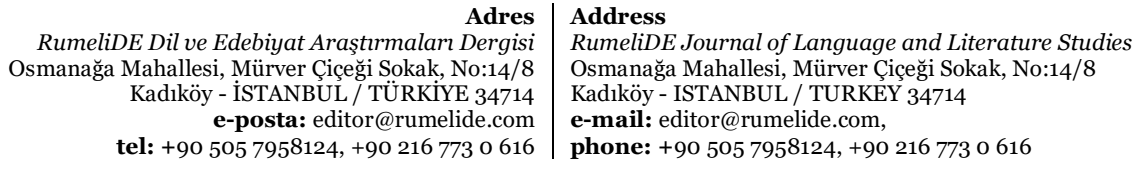


bir bakış açısı olan öznel odaklayımda okur olaylara anlatıcının gözünden bakamaz ve olayları yorumlayamaz. Bu bakımdan bu araştırmada öznel ve nesnel odaklayımın birlikte kullanıldığı öyküleyici metinlere yoğun bir şekilde yer verilmesi uygun olmuştur. Böylece okuyucu, anlatıcılarla rahatlıkla duygudaşlık kurup olayları yorumlayabilmiş, aynı zamanda öznel odaklayımın sunduğu imkânlarla olayları çok yönlü kavrayabilmiştir.

$\mathrm{Bu}$ araştırmada ikili odaklıyım, MEB ortaokul Türkçe ders kitaplarındaki sekiz öyküleyici metinde ve özel yayınevlerindeki altı öyküleyici metinde kullanılmıştır. Benöyküsel anlatıcı türünün görsel desteğiyle sunulduğu metinlerde görülen ikili odaklayım, her iki yayınevinin incelenen 14 öyküleyici metninde (\%14) bulunmaktadır. Bu sayı oldukça düşük denilebilir. Benzer şekilde Şen (2020) ortaokul ders kitaplarında bu odaklayım biçiminin yeterli düzeyde kullanılmadığını belirlemiştir. Şen (2020) bu metinlerde görsel ve metin uyumunun zayıf olduğunu, görsellerin slklıkla sadece arka fon işlevi gördüğünü ifade etmiştir. Ayrıca bu görsellerin kurguya eylem desteği vermediğini ve benöyküsel anlatıcıyla uyumlu olmadığını gözlemlemiştir. Bu araştırmada da ikili odaklayımın olduğu metinlerde kullanılan görsellerin yetersiz, çizimlerin ve renklendirmenin zayıf olduğu ve genelde arka fon işlevi gördüğü söylenebilir.

Bu araştırmada, MEB ortaokul Türkçe ders kitaplarında bulunan sadece bir metinde çoklu odaklayımın tercih edildiği, özel yayınevlerinde bulunan öyküleyici metinlerin hiçbirinde çoklu odaklayımın tercih edilmediği görülmüştür. Çoklu odaklayım biçiminin bulunduğu öyküleyici metinlere yer verilmemesi, sadece bir metinde vardır, ortaokul öğrencilerinin gelişim düzeyi açısından uygun bir yaklaşım olmuştur. Çünkü algılanması güç olan bu odaklayım türünün (Şen, 2020), gençlere seslenen örneklerinde bile iki sesten fazlasına yer verilmesi uygun değildir (Melrose, 2002). Ancak soyut işlemler dönemine geçen 8. sınıf öğrencileri için kullanılan ders kitaplarında bu odaklayım biçimi kullanılabilir. Bu sayede bu durum öğrenciler için yeni bir yazın deneyimi oluşturabilir (Şen, 2020). Sürekli aynı tür ve tarzda okumalar yapmaya alışmış öğrencilerin çoklu odaklayımın kullanıldığı metinlerle tanıştırılması onların yazın deneyimini zenginleştirerek farkındalık oluşturacaktır.

$\mathrm{Bu}$ araştırma sonuçlarına göre incelenen her iki yayınevinin ortaokul Türkçe ders kitaplarında yer alan öyküleyici metinlerinde sırasıyla elöyküsel, benöyküsel ve senöyküsel anlatıcı türlerinin kullanıldığı gözlemlenmiştir. Buna göre her iki yayınevinin öyküleyici metinlerinde bulunan anlatıcı türlerinin dağılımının birbirine benzediği söylenebilir. Ancak MEB ortaokul Türkçe kitaplarında bulunan öyküleyici metinlerde sınırlı elöyküsel anlatıcı daha fazla kullanılırken özel yayınevinin ortaokul Türkçe ders kitaplarında bulunan öyküleyici metinlerde sınırsız elöyküsel anlatıcı türü daha fazla kullanılmıştır. Başka bir deyişle elöyküsel anlatıcının alt türlerinin dağılımının birbirine benzemediği söylenebilir.

Anlatıcı türleriyle ilgili daha önce yapılan araştırmalarda Türkçe ders kitaplarında öznel odaklayım ve dışöyküsel anlatıcının egemen olduğu belirlenmiştir. Ayrıca içöyküsel anlatıcı türlerine yeterince yer verilmediği belirlenmiştir (Ercantürk, 2015; Sinan ve Demir, 2021; Şen, 2020). Buna göre Sinan ve Demir (2021) ve Ercantürk (2015) Türkçe ders kitaplarında bulunan öyküleyici metinlerin büyük çoğunluğunda sınırsız elöyküsel anlatıcının kullanıldığını gözlemlemiştir. Nitekim benzer şekilde bu araştırmada da incelenen öyküleyici metinlerde en fazla elöyküsel anlatıcı türünün kullanıldı̆̆ı, bununla beraber benöyküsel ve senöyküsel anlatıcı türlerine de daha fazla yer verilmeye başlandığ belirlenmiştir. Bu olumlu durumun araştırmalarda incelenen örneklem büyüklüğünden kaynaklandığı söylenebilir. Nitekim bu araştırma sonuçlarıyla benzer şekilde Şen’in (2020) yaptı̆̆ araştırmada ise benöyküsel ve senöyküsel anlatıcının biraz daha fazla yer tuttuğu görülmektedir. Sonuç olarak; ders kitaplarında anlatıcı türlerinin dağılımındaki oranın birbirine yaklaşması farklı anlatıcıların

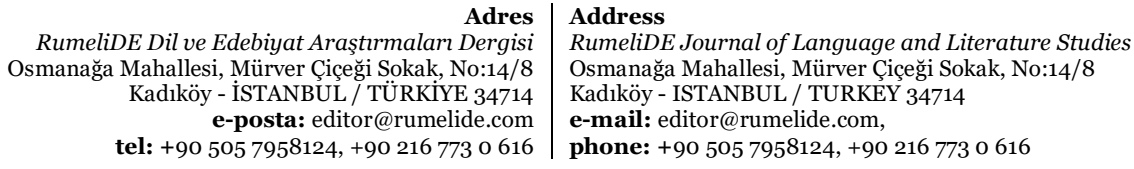


kullanımının sunduğu imkânları öğrencilerin fark etmesi açısından olumlu bir gelişmedir. Ancak ders kitaplarına seçilen öyküleyici metinlerde anlatıcı türlerinin dağılımının birbirine yaklaştırılması gerekmektedir çünkü Nikolejeva'ya göre (2014) anlatıcının öykü karakteriyle olan ilişkisinde ayrıcalıklı konuma yerleştirilmesi ortaokul öğrencilerinin özdeşim kurmasında sorun yaratabilir. Karakterle bağ kurmaya çalışan öğrenciler için otoriteyi temsil eden yetişkin sesin varlı̆̆ bu durumu güçleştirecektir. Daha önce yapılan araştırmalarla benzer şekilde bu araştırmada da incelenen öyküleyici metinlerde en az senöyküsel anlatıcının kullanıldığı belirlenmiştir. Şen’e (2020) göre bu duruma bağlı olarak çocuk okurda kurmaca-gerçeklik ilişkisine dönük bir farkındalık metin seçiminde ihmal edilmektedir. Buna karşın ortaokul öğrencileri gelişimsel özelliklerine uygun olarak ders kitaplarında anlatıcıların değişkenlik gösterdiği metinlerle karşılaştırılmalıdır (Canlı, 2014). Ancak incelenen ortaokul Türkçe ders kitaplarında anlatıcı türlerinin birlikte kullanıldığı metinlerin oranının (\%15) oldukça az olduğu görülmüştür.

Anlatıcıyla ilgili öğretim etkinliklerinin dağılımının incelendiği araştırma sonucunda MEB ortaokul Türkçe ders kitaplarında anlatıcı kavramına yer vermede tutarsızlık olduğu görülmüştür. Bu kavramla ilgili öğretim etkinliklerine en fazla 8. sınıfta, en az ise 7. sınıf düzeyinde yer verildiği belirlenmiştir. Özel yayınevlerinin ortaokul Türkçe ders kitaplarında anlatıcı kavramına yer vermede yine tutarlık olmadığı görülmüştür. Anlatıcı kavramıyla ilgili öğretim etkinliklerine en fazla 5 . sınıfta yer verildiği, 8. sınıfta ise hiç yer verilmediği görülmüştür. Hatta özel yayınevlerinin ortaokul Türkçe ders kitaplarında sınıf düzeyi arttıkça bu kavramla ilgili öğretim etkinliklerinin oranının devamlı düştüğü gözlemlenmiştir. Bu sonuçlara göre anlatıcı öğretim etkinliklerinin dağılımında ortaokul öğrencilerinin gelişim düzeyinin göz önünde bulundurulmadığı, aşamalığın takip edilmediği söylenebilir. Bu bağlamda Demir (2008) 6 . sınıf öğrencilerinin çoğunlukla metinde kullanılan anlatıcı türünü doğru tespit edemediğini; öğrencilerin dışöyküsel anlatıcıyı, benöyküsel anlatıcı ile karıştırdığını bulgulamıştır. Buna karşın 7 . sınıf öğrencilerinin benöyküsel anlatıcıyı, 8. sınıf öğrencilerinin ise elöyküsel anlatıcıyı yüksek oranda doğru belirleyebildiğini tespit etmiş̧ir.

Anlatıcıyla ilgili öğretime etkinliklerinin kurgusu ve bu kavramla ilgili kullanılan terimler incelendiğinde; MEB ortaokul Türkçe ders kitaplarında anlatıcıyla ilgili öğretim etkinliklerinin dört farklı grupta toplandığı görülmüştür. Bunlar: hikâyenin bileşenlerini çözümleme, doğru/yanlış sorusu, farklı metinlerin anlatıcılarını karşılaştırma, bağımsız öğretim etkinliğidir. Özel yayınevlerinin ortaokul Türkçe ders kitapları incelendiğinde; anlatıcıyla ilgili öğretim etkinliklerinin iki farklı grupta toplandığı görülmüştür. Bunlar: hikâyenin bileşenlerini çözümleme ve bağımsız öğretim etkinliğidir. Bu sonuçlara göre; MEB yayınevinin ders kitaplarında anlatıcıyla ilgili kurgulanan öğretim etkinliği biçiminin özel yayınevlerinin ders kitaplarına göre daha farklı biçimde olsa da her iki yayınevinde kurgulanan öğretim etkinliklerinin birbirine benzediği gözlemlenmiştir. Ayrıca bu öğretim etkinliklerinin birbirine benzer şekilde devamlı metin çözümleme üzerinde yoğunlaştı̆̆ı, buna karşın metin üretmeyle ilgili 6. sınıf düzeyinde sadece bir etkinliğin kurgulandığı gözlemlenmiştir. Böyle bir durumda öğrencilerin anlatıcı kavramıyla ilgili bildiklerini uygulama boyutuna yani yazma sürecine taşıyamayacakları söylenebilir. Ortaokul süreci boyunca öğrencilerin yazılarının birbirine benzemesi, öğrencilerin yazma sürecine başlama ve süreci yönetmede zorlanması; bu sonucun ortaya çıkarabileceği olumsuz durumlar arasindadır.

Anlatıcıyla ilgili ortaokul Türkçe ders kitaplarında kullanılan terimler incelendiğinde; MEB ve özel yayınevlerinin ortaokul Türkçe ders kitaplarında anlatıcı, birinci ve üçüncü tekil kişi ağzı, birinci-üçüncü kişili anlatım ve bakış açısı terimlerinin kullanıldı̆̆ı; yine her iki yayınevinin kitaplarında terim birliğinin olmadığı gözlemlenmiştir. Anlatıcı için her sınıf düzeyinde farklı bir terimin kullanılması,

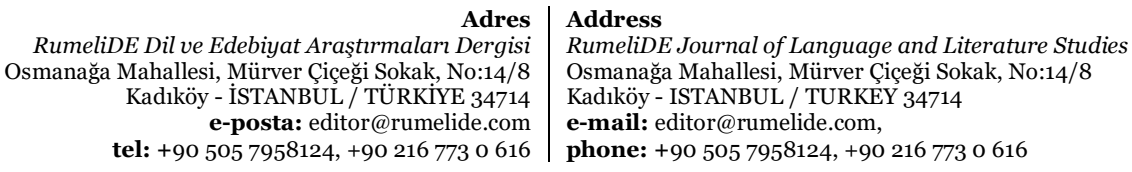


ortaokul öğrencilerinde kavram yanılgısına neden olabilir. Ayrıca bu bulgulara göre, anlatıcı türlerinin dağılımıyla ilgili bulgularla benzer şekilde senöyküsel anlatıcıyla ilgili hiçbir terimin kullanılmadığı anlaşılmaktadır.

Gerçek dünyaya ait olan yazar, ürettiği öyküleyici metin kurgusunun tamamen dışındadır ve metnin her türlü sorumluluğunu alan kişidir (Kıran ve Kıran, 2003). Metne ait bir bileşen olan anlatıcı kavramı ise öyküleyici metinlerde öyküyü anlatan kişidir. Buna göre öyküleyici metinleri incelerken yapılacak ilk iş yazar ve anlatıcıyı birbirinden ayırmayı başarmaktır. 6. sınıf öğrencilerinin yazar ile anlatıcıyı birbirine karıştırdığı ve çoğunlukla metinde kullanılan anlatıcı türünü doğru tespit edemedikleri belirlenmiştir. (Demir, 2008). Bu araştırmada ise ortaokul Türkçe ders kitaplarında bulunan öğretim etkinlikleri incelendiğinde MEB 5. sınıf ve özel yayınevi 8. sınıf ortaokul Türkçe ders kitaplarında yazar ve anlatıcı karmaşasının bulunmadığı; buna karşın her iki yayınevinin bütün sınıf düzeylerinde bu karmaşanın bulunduğu gözlemlenmiştir. İncelenen öyküleyici metinlerle ilgili hazırlanan metin içi sorularda yazar ile benöyküsel anlatıcı, senöyküsel anlatıcı, sınırsız ve sınırlı elöyküsel anlatıcı karmaşasının olduğu gözlemlenmiştir. Buna göre öğretim etkinliklerinin en önemli aracı olan ders kitaplarında yazar ve anlatıcı karmaşasının bulunması öğrencilerin bu kavramlarla ilgili yanılgılarını artırabilir. Sonuç olarak, öyküleyici metinlerde anlatıcı kurgu dünyasının bir unsurudur ve varlığı okuyucuya bağlıdır. Başka bir deyişle, anlatıcının varlığı okuyucunun metinle kurduğu ilişki ve teması var oldukça sürebilir. Bunun dışında anlatıcının gerçek dünyayla bağı kopar, fakat yazarın bu bağ için başka kimselere ihtiyacı yoktur.

\section{Öneriler}

$\mathrm{Bu}$ araştırmadan elde edilen sonuçlar ve alanyazın sonuçlarının tartışılması temelinde şu öneriler getirilebilir:

Ders kitaplarına metin seçimi sırasında öyküleyici metinlerin anlatıcı tür ve odaklayım dağılımının birbirine yakın olması sağlanabilir. Özellikle ders kitaplarında yer alan ikili odaklayım örneklerinde görsel ve metin uyumu güçlendirilebilir. Ortaokul seviyesinde anlatıcıyla ilgili öğretim etkinliklerinin dağılımında tutarlık sağlanabilir. Öğrencilerin gelişim düzeyi göz önünde bulundurulup kolaydan zora, somuttan soyuta ilkeleri takip edilebilir. Anlatıcıyla ilgili öğretim etkinlikleri; sadece çözümleme amacıyla değil, öğrencilerin yazın deneyimini artırması için yazı üretme temelinde tasarlanabilir. Ortaokul seviyesinde anlatıcıyla ilgili kavram yanılgılarının önüne geçmek için anlatıcı kavramı etrafında kullanılan terimlerde birlik sağlanabilir. Öğretim etkinliklerinde kullanılan metin içi sorularda daha titiz davranılabilir, anlatıcı-yazar karmaşasına son verilebilir. Özellikle üst düzey bilişsel süreçlere yönelik sorular sorulabilir.

\section{Kaynakça}

Barthes, R. (2005). Göstergebilimsel serüven. (Çev. Mehmet-Sema Rifat). İstanbul: Yapı Kredi.

Beard, A. (2001). Texts and contexts an introduction to literature and language study. London: Routledge.

Beard, A. (2003). The language of literature. London and New York: Routledge.

Bennett, A., ve Royle, N. (2016). Şu edebiyat denen şey (okumak, düşünmek, yazmak). İstanbul: Notos Kitap.

Büyüköztürk, Ş., Kılıç Çakmak, E., Akgün, Ö. E., Karadeniz, Ş., ve Demirel, F. (2015). Bilimsel araştırma yöntemleri. (19. Baskl). Ankara: Pegem Akademi.

Canll, S. (2014). Türkçe ders kitaplarma seçilecek metinlerin niteliği üzerine bir araştırma, (Yayınlanmamış Doktora Tezi). Ankara Üniversitesi, Eğitim Bilimleri Enstitüsü, Ankara.

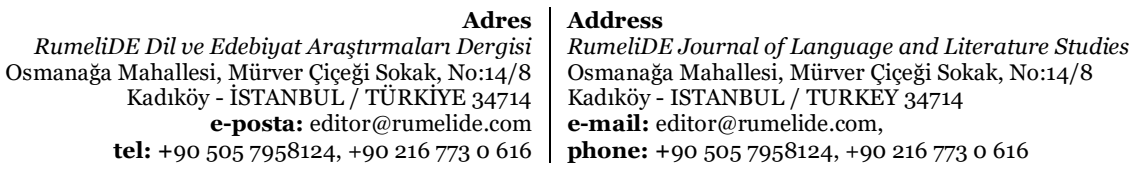


Demir, S. (2008). İlköğretim 6, 7 ve 8. sinıflar Türkçe ders kitaplarmdaki öykülerin metin dilbilimsel yöntemlerle incelenmesi ve bu metinlerin öğrencilerin anlama düzeylerine etkisi (Malatya ili örneği) (Yayınlanmamış Yüksek Lisans Tezi). Fırat Üniversitesi, Eğitim Bilimleri Enstitüsü, Elazı̆g.

Dilidüzgün, S. (2004). Çağdaş çocuk yazını. İstanbul: Morpa Kültür.

Ercantürk, O. K. (2015). Göstergebilim açısından Türkçe ders kitapları. Uluslararası Sosyal Araştırmalar Dergisi, 8(36), 93-109.

Fraenkel, J.R. \& Wallen, N.E. (2006). How to desing and evaluate research in education. New York: McGraw-Hill International Edition.

Gülsoy, M. (2014). Büyübozumu: Yaratıcı yazarlı. İstanbul: Can.

Günay, V. D. (2003). Metin bilgisi. İstanbul: Multilingual.

Kale, Ö. (2017). Anlatıcının macerası. Dede Korkut Uluslararası Türk Dili ve Edebiyatı Araştırmaları Dergisi, (6)12, 41-47.

Karasar, N. (2012). Bilimsel araştırma yöntemi. Ankara: Nobel.

Kuran, A. E., ve Kıran, Z. (2003). Yazınsal okuma eüreçleri. Ankara: Seçkin.

MEB. (2018). Türkçe dersi öğretim programı (ilkokul ve ortaokul 1, 2, 3, 4, 5, 6, 7ve 8. simfflar). Ankara: Milli Eğitim Bakanlığı.

Melrose, A. (2002). Write for children. London: Routledge Falmer.

Miles, M. B. \& Huberman, A.M. (1994). Qualitative data analysis : An expanded source book. (2nd Edition). California : SAGE.

Nikolajeva, M. (2014). Reading for learning (cognitive approaches to children's literature). Amsterdam: John Banjamins.

Özdemir, E. (2007). Eleştirel okuma. Ankara: Bilgi.

Öztokat, N. T. (2005). Yazınsal metin çözümlemesinde kuramsal yaklaşımlar. İstanbul: Multilingual.

Sever, S. (2013). Çocuk ve edebiyat. İzmir: Tudem.

Sinan, A. T., ve Demir, S. (2021). İlköğretim ikinci kademe Türkçe ders kitaplarındaki anlatısal metinlerin yapı özellikleri ve programa uygunluğu. Turkish Studies, 6(3), 1149-1167. dol:http://dx.doi.org/10.7827/TurkishStudies.2629

Sözen, M. (2008). Anlatıcı kavramı, sinematografide anlatıcı tipolojisi ve örnek çözümlemeler. Selçuk İletişim (5)2, 167-182.

Şen, E. (2020). Ortaokul Türkçe ders kitaplarında yer alan kurmaca metinlerin "odaklayım" ve "anlatıcı" açısından incelenmesi. Turkish Studies-Education, 15(4), 2961-2980. https://dx.doi.org/10.47423/TurkishStudies.41712

Tekin, M. (2009). Roman sanat romanın unsurları I. İstanbul: Ötüken.

Yıldırım, A. ve Şimşek, H. (2013). Sosyal bilimlerde nitel araştırma yöntemleri (9. Baskı). Ankara: Seçkin.

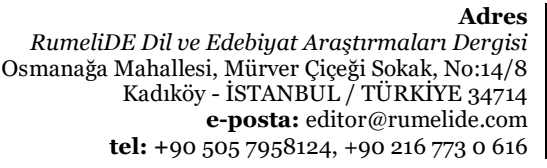

res

RumeliDE Journal of Language and Literature Studies

Osmanağa Mahallesi, Mürver Çiçeği Sokak, No:14/8

Kadıköy - ISTANBUL / TURKEY 34714

e-mail: editor@rumelide.com,

phone: +90 $5057958124,+902167730616$ 